1996

\title{
INOPAL II Final Report
}

Population Council

Follow this and additional works at: https://knowledgecommons.popcouncil.org/departments_sbsr-rh

Part of the Family, Life Course, and Society Commons, Health Services Research Commons, and the International Public Health Commons How does access to this work benefit you? Let us know!

\section{Recommended Citation}

"INOPAL II Final Report." Washington, DC: Population Council, 1996.

This Report is brought to you for free and open access by the Population Council. 
THE POPULATION COUNCIL

INOPAL II PROJECT

January 26, 1996 


\section{CONTENTS}

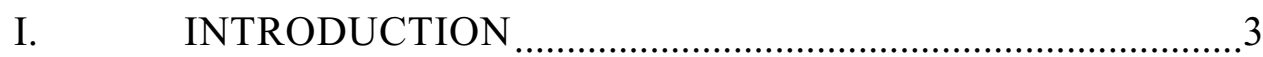

II. PROJECT ACTIVITIES _..........................................................

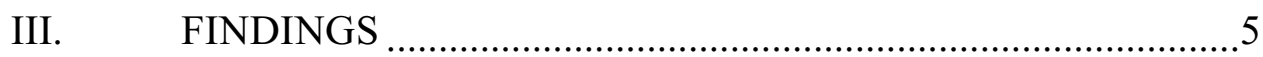

IV. INSTITUTIONALIZATION OF

OPERATIONS RESEARCH CAPABILITY ……....................27

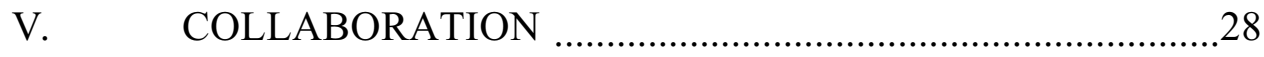

VI. $\quad$ LIST OF INOPAL II FINAL REPORTS ……............................

VII. PUBLISHED ARTICLES AND PRESENTED PAPERS .............. 


\section{INTRODUCTION}

INOPAL is the acronym for the Population Council's "Investigación Operacional en Planificación Familiar y Atención Materno-Infantil para América Latina y el Caribe" program. Its goal is to conduct operations research (OR) and provide technical assistance (TA) to improve the coverage, quality, and sustainability of family planning services in Latin America and the Caribbean (LAC). Family planning operations research is the use of social science techniques to improve programs. OR is distinguished from other family planning research by its focus on factors under the control of managers. Independent variables in OR projects are manipulable by administrators, and dependent variables are outcomes of high value to programs.

INOPAL II was the successor to INOPAL I (1984-1989). Like its predecessor, INOPAL II was supported by a contract from the USAID Office of Population between 1989-1995, when it was replaced by a new USAID-funded project, INOPAL III. Specific INOPAL II objectives included:

1. Expanding access to family planning services.

2. Improving the op erations of programs by making them more efficient.

3. Increasing access to the full range of contraceptive methods.

4. Providing more services to special population groups, including postpartum women, men, indigenous populations, and young adults.

5. Imp roving program quality.

INOPAL II had offices in Lima, Peru; Mexico City, Mexico; Bolivia, Guatemala, Haiti, and Honduras. Program administration was handled by the Population Council's New York office. The program emp loy ed seven researchers, a dissemination specialist, and support staff. INOPAL II also trained and supported a University of Michigan Population Fellow and six local Fellows from five countries (Peru, Bolivia, Guatemala, Haiti, and Honduras) in OR techniques. Dissemination activities included newsletters, conferences, handbooks, and publications.

In addition to reporting on the activities carried out by the INOPAL II program, this rep ort summarizes major research findings and discusses the effect of individual OR sub-p rojects on family planning programs. Readers interested in more in-depth information on INOPAL II sub-projects will find a list of presented papers, publications, and final sub-project technical reports at this end of this report. Sub-project final rep orts are available from INOPAL by writing INOPAL III, The Population Council, 1 Dag Hammarskjold Plaza, NY, NY 10017. 


\section{PROJECT ACTIVITIES}

The INOPAL II contract called for 33-43 sub-projects in five years. The Population Council actually completed 61 sub-projects as shown in Table 1.

Table 1

INOPAL II sub-project status through March, 1995

\begin{tabular}{||l|c||}
\hline COUNTRY & NUMBER \\
\hline \hline BOLIVIA & 7 \\
\hline BRAZIL & 3 \\
\hline COLOMBIA & 1 \\
\hline ECUADOR & 8 \\
\hline GUATEMALA & 5 \\
\hline HAITI & 3 \\
\hline HONDURAS & 6 \\
\hline MEXICO & 11 \\
\hline NICARAGUA & 1 \\
\hline PARAGUAY & 1 \\
\hline PERU & 15 \\
\hline \hline TOTAL & 61 \\
\hline \hline
\end{tabular}

In addition to projects with formal sub-contracts, INOPAL II co-sponsored and provided TA to 21 seminars and workshops sponsored by other agencies.

Public sector agencies were an INOPAL II priority: 31 of the sub-projects had one or more public sector participants, 28 were exclusively with nongovernmental organizations (NGOs), and two were with for-profit organizations. INOPAL II sub-projects can be divided into three broad categories: Thirty-five field-tested or modeled service-delivery interventions, 17 were TA or institutionalization projects such as seminars and evaluations, and nine were diagnostic activities such as situational analy ses and qualitative studies. The map in figure 1 shows the locations of INOPAL II operations research activities. (See Figure 1.) 


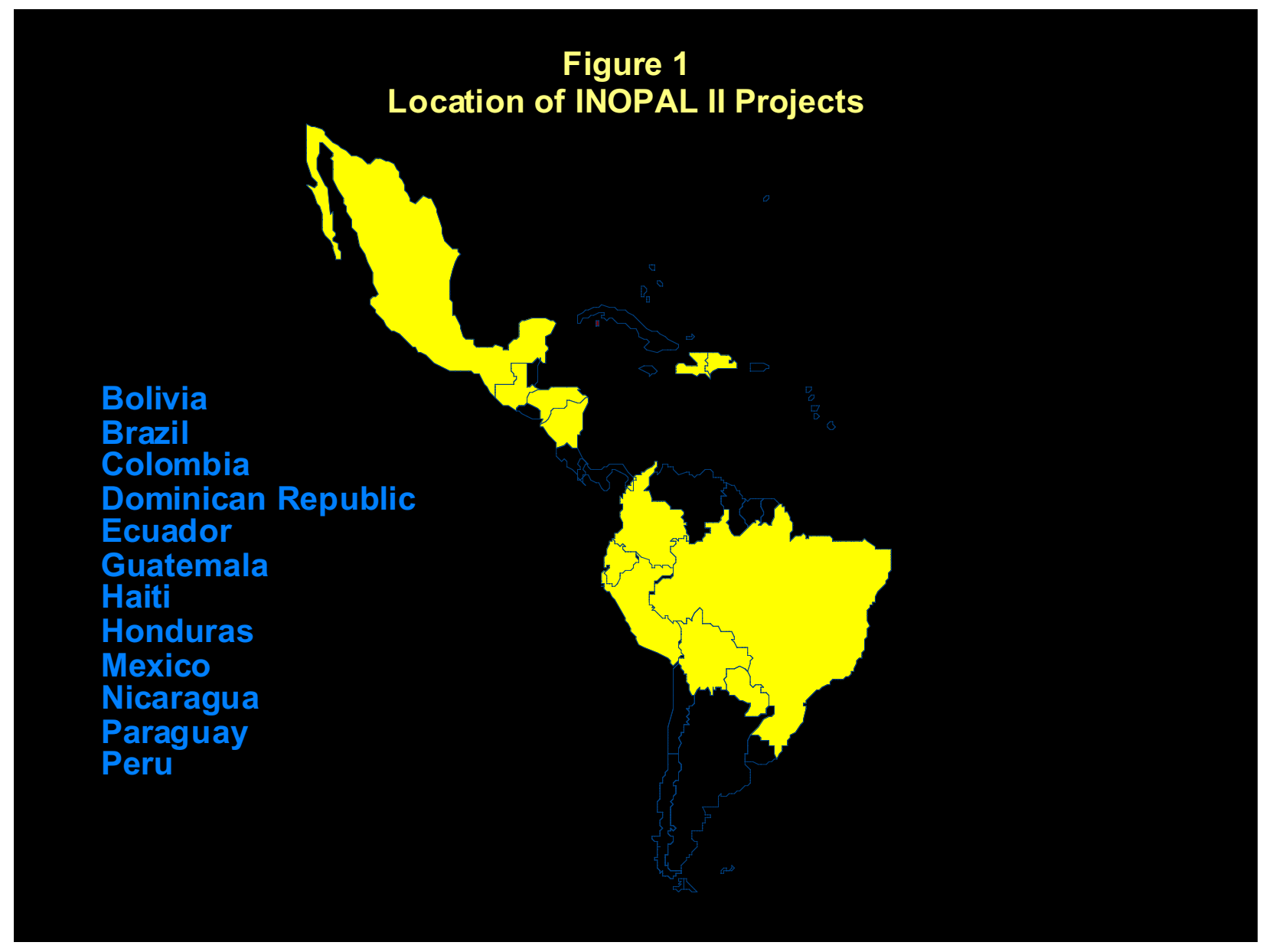

A basic indicator of the success of an operations research program like INOPAL is the number of tested service-delivery interventions that were adopted as a routine part of program operations. Thirty-five INOPAL II studies tested or modeled interventions that attempted to improve program processes and outcomes. Interventions or recommended alternatives were adopted and/or scaled-up in 30 projects. INOPAL II projects helped establish or changed services for postpartum women as well as programs for adolescents and rural women. OR also changed vasectomy and Depo-Provera promotion strategies, improved program quality, increased financial sustainability of programs, and helped integrate family planning with other reproductive health activities. Table 2 shows the number of intervention projects conducted in each country, and the number of projects that were adopted or scaled-up. 
Table 2

Number of INOPAL II intervention projects scaled-up by country

\begin{tabular}{|l|c|c||}
\hline \multicolumn{1}{|c|}{ COUNTRY } & $\begin{array}{c}\text { INTERVENTION } \\
\text { PROJECTS }\end{array}$ & $\begin{array}{c}\text { ADOPTED/ } \\
\text { SCALED-UP }\end{array}$ \\
\hline \hline BOLIVIA & $\mathbf{3}$ & $\mathbf{3}$ \\
\hline BRAZIL & $\mathbf{2}$ & $\mathbf{2}$ \\
\hline COLOMBIA & $\mathbf{1}$ & $\mathbf{0}$ \\
\hline ECUADOR & $\mathbf{4}$ & $\mathbf{4}$ \\
\hline GUATEMALA & $\mathbf{2}$ & $\mathbf{2}$ \\
\hline HAITI & $\mathbf{1}$ & $\mathbf{1}$ \\
\hline HONDURAS & $\mathbf{6}$ & $\mathbf{5}$ \\
\hline MEXICO & $\mathbf{5}$ & $\mathbf{5}$ \\
\hline NICARAGUA & $\mathbf{1}$ & $\mathbf{1}$ \\
\hline PARAGUAY & $\mathbf{1}$ & $\mathbf{1}$ \\
\hline PERU & $\mathbf{9}$ & $\mathbf{6}$ \\
\hline \hline TOTAL & $\mathbf{3 5}$ & $\mathbf{3 0}$ \\
\hline
\end{tabular}

\section{FINDINGS}

This section presents operations research findings from INOPAL priority research areas including financial sustainability, provision of services to special populations, and quality of care. It also discusses specific changes in family planning programs that occurred as a result of OR.

\section{A. FINANCIAL S US TAINABIUTY}

Financial sustainability is the ability of a family planning agency to continue providing services when traditional donor financial support is reduced or withdrawn. Donor funding for many family planning organizations, especially NGOs, is being reduced or eliminated. Replacing donor funds with locally generated income has become the first priority in LAC. Operations Research results suggest that financial sustainability requires (1) continuous efforts to generate income, (2) cost recovery, and (3) cost control. Some sustainability OR has also revealed difficult-to-overcome contradictions between an agency's need to be self-sufficient and its mission to provide contraceptive services to the poor. 


\section{n Income Generation}

Income generation refers to selling services for profit. A commonly tried strategy among LAC family planning organizations is to add profit-making services such as laboratory tests and ultrasound services to cross-subsidize nonprofit family planning activities.

Because even medium-sized family planning NGOs now have annual budgets approaching \$1 million, most individual income-generating activities contribute only a relatively small amount to agency sustainability.

n CEMOPLAF of Quito, Ecuador, began selling ultrasound services at market prices. Although earning several thousand dollars per year in net profit, ultrasound services increased the agency's overall sustainability by only $2 \%$. Recognizing the need to develop an in-house capacity to continuously test and implement new sustainability schemes, CEMOPLAF requested and received INOPAL assistance in institutionalizing the ability to conduct cost- and income-related research. (CEMOPLAF II)

\section{n Cost Recovery}

Cost recovery refers to the prices charged for family planning and other services. If prices are set too low, the program needlessly subsidizes the middle class. If prices are set too high, the poor are denied access to services. Because loss of subsidized clients is not detrimental to selfsufficiency, cost-recovery efforts can bring the need for financial sustainability into conflict with the program goal of serving the poorest.

NGO and public-sector prices for most contraceptive methods are usually verylow. Thus, only large price increases reduce numbers of users.

$n$ CEMOPLAF conducted a market survey and found that the average client spent less than $1 \%$ of annual family income on an IUD insertion and one year of related services. The poorest $20 \%$ of clients spent less than $2 \%$ on one year of IUD services and the wealthiest $20 \%$ less than $0.5 \%$. As a result of the survey, agency clinics raised prices by ap proximately $20 \%$. (CEMOPLAF II)

$\mathrm{n}$ In INOPAL projects, large, sustained client loss only occurred when prices were increased by $50 \%$ or more. APROFE is the largest family planning NGO in Ecuador. Service statistics on new IUD acceptors from 16 clinics indicated that new-client decline was produced only when price increases reached $50 \%$. The agency allowed clinic directors to set their own IUD insertion prices. Prior to the experiment, the cost of an IUD insertion in all clinics was approximately $\$ 3.33$. Price increases ranged from $0-50 \%$. Figure 2 shows the impact of the increases on program acceptance. (See Figure 2.) 


\section{Figure 2 APROFE, Ecuador Changes in IUD Demand by Price Changes}

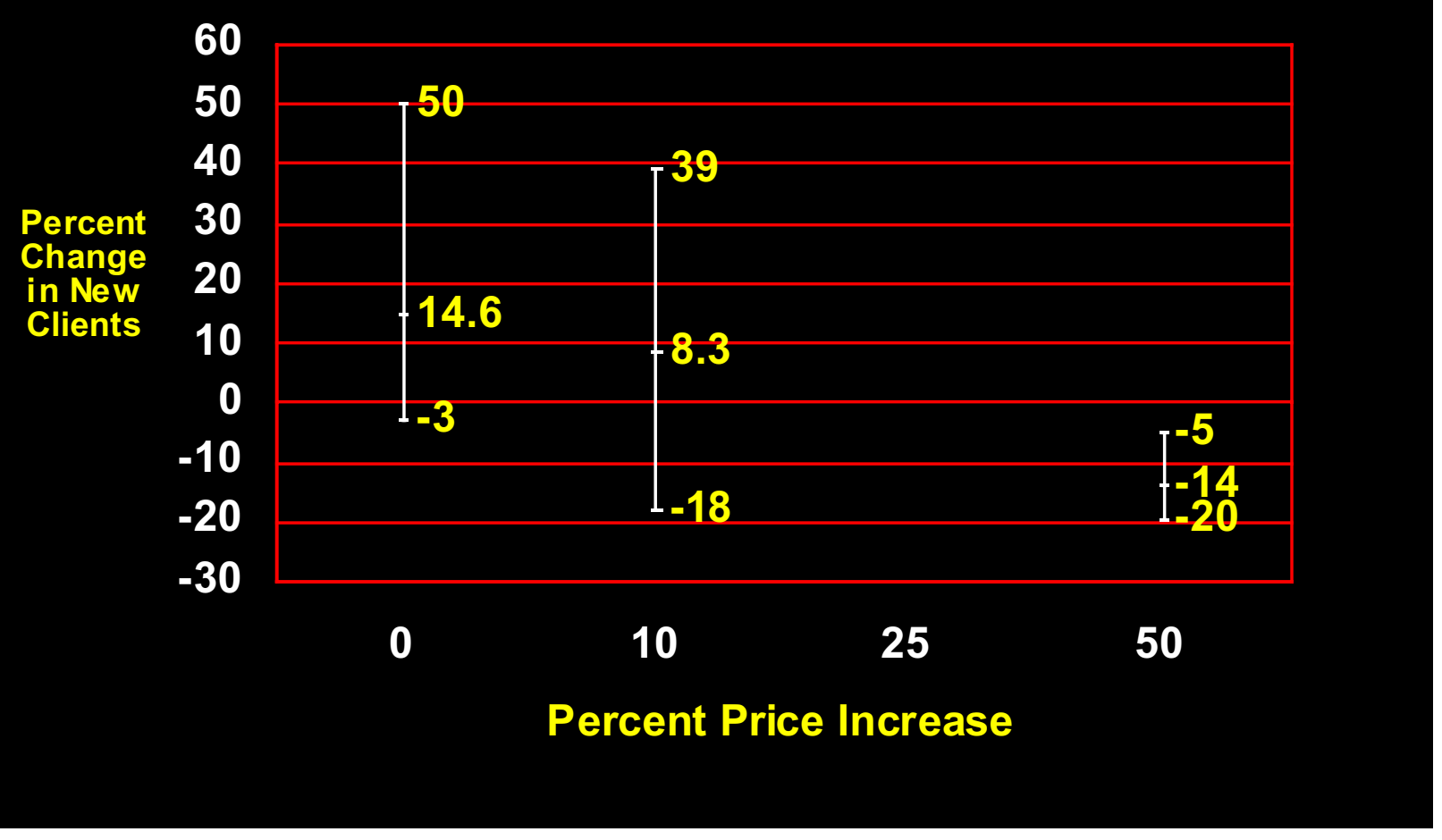

The horizontal axis shows the percent price increases over the baseline period August 1990-July 1991. The vertical axis shows the percent change in new clients during the quarter following the price increases. The bars give the range of percent change in new clients experienced by the clinics in each group. Clinics not raising prices had an average increase in new clients of $14.6 \%$. Modest price increases of about 10\% had little impact on new clients (an average increase of about $8 \%$ was experienced by the group, but some clinics experienced client losses as great as 18\%). Price increases of approximately 50\% (from $\$ 3.33$ to $\$ 5.00$ ) resulted in an average $14 \%$ decline in insertions. The study showed that sustainability and client loss were not incompatible. The clinic that increased prices the most suffered the greatest decline in new clients but also achieved the greatest level of financial self-sufficiency. (APROFE)

n Community-based distribution (CBD) programs in Lima and Ica, Peru, exp erimented with selling a social marketing oral contraceptive, Microgy non, at the commercial price of $\$ 0.50$ per cycle. Laboratory price increases forced the programs to raise prices by $145 \%$, and Microgynon sales declined by approximately $75 \%$. In the pharmacy sector, which serves a more affluent market segment than does CBD, the $145 \%$ price increase reduced Microgynon sales by about $50 \%$. (Apoyo a Programas de Población) 
n Figure 3 shows the impact of price on quantity of NORPLANT sold by PROFAMILIA of Colombia. Three times more NORPLANT was sold at \$16 than at \$32. (See Figure 3.)

\section{Figure 3 \\ PROFAMILIA, Colombia \\ Mean Quarterly Norplant Sales at Three Prices}

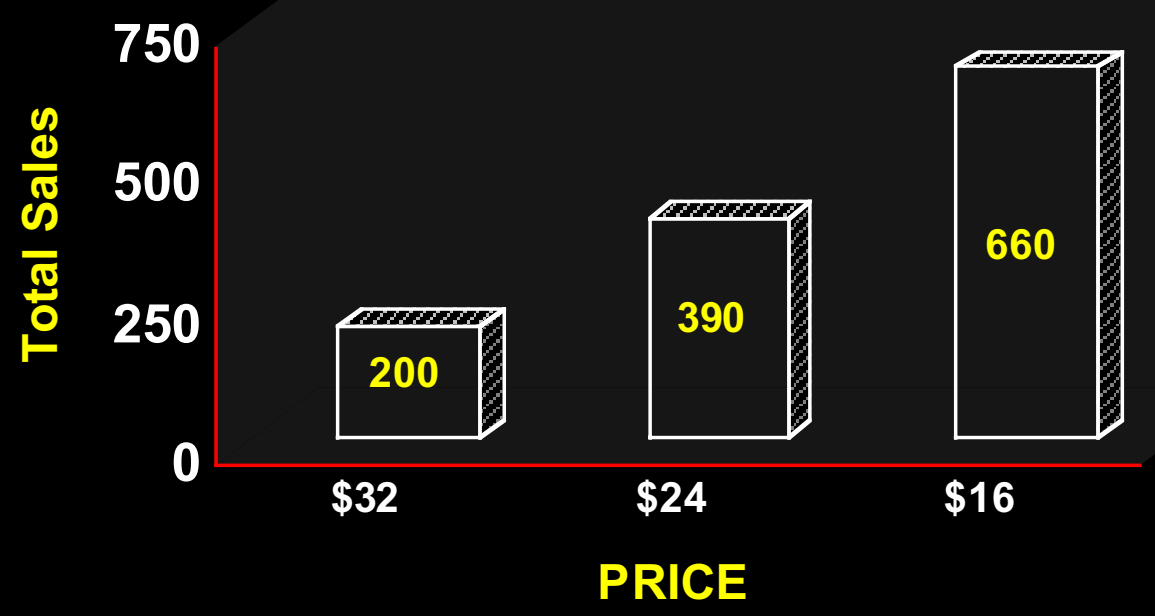

The more expensive a method becomes, the more affluent becomes the user profile.

$\mathrm{n}$ NORPLANT is a relatively expensive method of family planning. PROFAMILIA of Colombia estimates that the initial cost of implanting the method is approximately $\$ 32$. The agency experimented with setting prices ranging from \$16-\$32, making NORPLANT the contraceptive with the highest initial price of all temporary methods offered by the agency. As shown in Table 3, NORPLANT acceptors were of higher socio-economic status than users of other temporary methods in the same clinics. Thus, the addition to programs of initially higher-priced methods may be of little or no benefit to poor users. And if high-priced methods are not sold at a profit, they may also be of no benefit to program sustainability. (PROFAM ILIA) 
Table 3

PROFAMILIA, Colombia

Percent distribution:

Socio-economic status comparison of NORPLANT users and users of other temporary methods

\begin{tabular}{||l|c|c|c||}
\hline \multirow{2}{*}{\begin{tabular}{c} 
METHOD \\
\cline { 2 - 4 }
\end{tabular}} & \multicolumn{3}{|c|}{ SOCIO-ECONOMIC ST ATUS } \\
\cline { 2 - 4 } & HIGH & MEDIUM & LOW \\
\hline \hline NORPLANT & $25 \%$ & $71 \%$ & $4 \%$ \\
\hline OTHER TEMPORARY & $16 \%$ & $70 \%$ & $14 \%$ \\
\hline
\end{tabular}

Price increases have a smaller impact on overall contraceptive use than on source use because users who drop out of a program for economic reasons switch to less expensive sources.

$\mathrm{n}$ Most women who abandon a source for economic reasons seek other, less expensive services. Figure 4 compares subsequent contraceptive use among women who dropped out of a Peruvian private, nonprofit CBD program by reason for drop-out. (See Figure 4.)

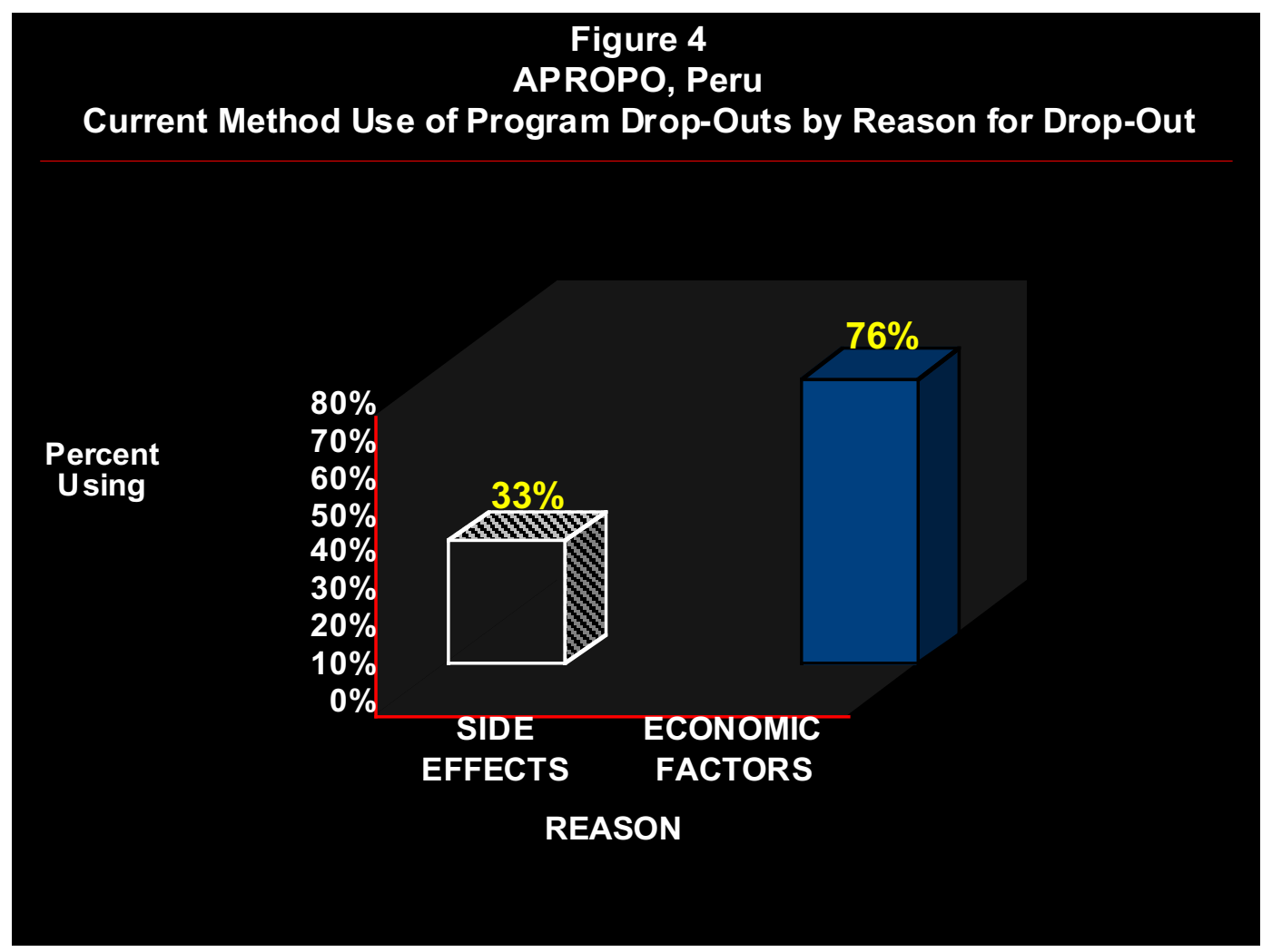


Women who drop out for side effects are much less likely to be using a contraceptive than women who drop out because of a price increase. Most economic drop-outs transferred to the Ministry of Health. (APROPO)

Even fairly large price increases in a single program component may result in only modest increases in the financial sustainability of the entire institution.

n Like income generation, isolated cost-recovery efforts are unlikely to have a large impact on overall institutional sustainability. CEMOPLAF raised the prices of clinic services an average of $20 \%$. Clinic income increased by approximately the same amount, and sustainability increased an estimated 2-3\%. (CEMOPLAF II)

\section{n Cost Control}

Cost control means using resources more efficiently. It means serving the same number of family planning users with fewer resources, or, conversely, more users with the same resources.

Sustainability, quality, and access are interrelated. Administrators must realize that changes in one factor will affect the others. However, these impacts are not always negative. INOPAL has found that cost-control projects usually have a positive or neutral impact on quality and access.

n Centro de Orientación para Adolescentes, A.C. (CORA) operated a program for adolescent mothers consisting of education, counseling, and family planning in the Hospital de la Mujer in Mexico City, Mexico. The program was too costly for extension to other hospitals. A systems analy sis was conducted which found that $64-78 \%$ of program-employee time was spent in nonproductive activities. CORA consolidated its program by reducing the number of employees, but did not eliminate services. Cost-effectiveness doubled. Cost reductions allowed the program to be replicated with public and other donor funds in five additional Mexico City hospitals. These hospitals, along with the Hospital de la Mujer, attend almost 5,000 births to adolescents every year. (CORA)

n El Centro Paraguayo de Estudios en Población (CEPEP) of Paraguay tested a low-cost alternative to the traditional three-day retraining course for rural CBD workers. The course included lectures on reproduction, as well as practical aspects of providing contraception and role-playing exercises to improve counseling skills. Alternative retraining consisted of instruction in the use of a decision tree (the ABC of Primary Care in Family Planning) for client counseling for a period of less than one hour. CEPEP compared the two training sy stems on cost and quality. ABC training was less costly and resulted in higher quality than traditional training, as shown in Figure 5 . The line in Figure 5 represents costs and the bars represent quality-of-care scores derived from checklists filled out by simulated clients. The agency adopted the $\mathrm{ABC}$ for use by all community-based distributors (CEPEP). The ABC was later adopted by the Ministry of Health in Peru for use by fieldworkers (Instituto Andino de Estudios en Población y Desarrollo II), and by NGOs in Haiti. (See Figure 5.) 


\section{Figure 5 \\ CEPEP, Paraguay}

\section{Dollar Costs and Quality Scores of Two CBD Training Schemes}

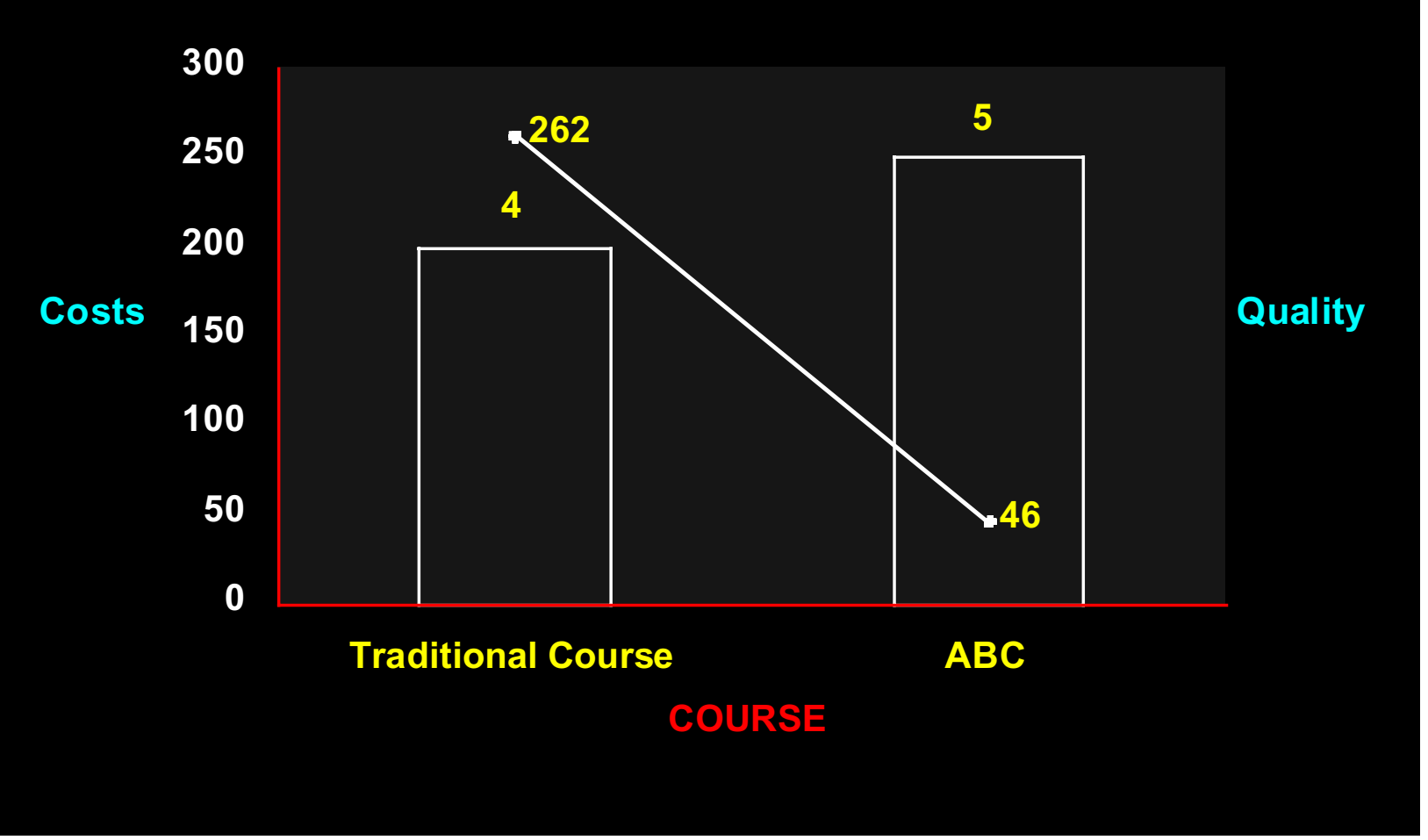

$\mathrm{n}$ Table 4 shows how choosing an IUD revisit norm forces programs to confront the problem of balancing costs and access against problem detection. CEMOPLAF felt that its IUD revisit norm of four required revisits was too costly for the agency and clients. Moreover, most CEMOPLAF clinics were at or near capacity, and client access was becoming a problem. CEMOPLAF was, however, concerned that reducing revisits would increase the number of undetected medical problems. The agency conducted an OR study to model the impact of three different norms on problem detection (expulsion, PID, pregnancy), costs, and access (reduction in revisits). 
Table 4

Problems detected, number of revisits and costs

per 10,000 insertions, for three IUD revisit norms

\begin{tabular}{||c|c|c|c|c||}
\hline \hline NORM & $\begin{array}{c}\text { PROBLEMS } \\
\text { DETECTED } \\
\text { PER YEAR }\end{array}$ & $\begin{array}{c}\text { NUMBER } \\
\text { OF } \\
\text { REVISITS } \\
\text { PER YEAR }\end{array}$ & $\begin{array}{c}\text { NET AGENCY } \\
\text { COST PER } \\
\text { YEAR }\end{array}$ & $\begin{array}{c}\text { TOT AL } \\
\text { ACCEPTOR + } \\
\text { AGENCY) COST } \\
\text { PER YEAR }\end{array}$ \\
\hline \hline $\begin{array}{c}4 \text { required } \\
\text { revisits in } \\
\text { first year }\end{array}$ & 582 & 23,100 & $\$ 28,000$ & $\$ 100,000$ \\
\hline $\begin{array}{c}1 \text { required revisit } \\
\text { in } \\
\text { first year, others } \\
\text { optional }\end{array}$ & 527 & 14,800 & $\$ 18,000$ & $\$ 64,000$ \\
\hline $\begin{array}{c}\text { All revisits } \\
\text { optional }\end{array}$ & 423 & 8,300 & $\$ 10,000$ & $\$ 36,000$ \\
\hline
\end{tabular}

CEMOPLAF switched from the four revisit norm to a one revisit norm (the all revisits optional norm was rejected because providers felt it would result in too many missed problems). The new norm was sup erior in terms of costs and access, and reduced problem detection by only 55 problems per 10,000 insertions. Cost savings contributed approximately $1.5-2 \%$ to overall agency sustainability. The project also reduced client costs including travel, price of service, and the opportunity cost of time spent revisiting. (CEMOPLAF I)

\section{n SELF-S US TAINING AND FOR-PROFIT ORGANIZATIONS}

Attracting new organizations to family planning increases the availability and variety of service and information outlets, and adds organizations that do not compete for national or international donor family planning resources. Increasing the participation of self-sustaining and forprofit groups in family planning makes it possible for some clients to transfer from subsidized public sector and NGO organizations to self-supporting medical insurance plans and HMOs.

For-profit organizations can be persuaded to offer family planning by demonstrating the cost savings that the service can produce.

n Medical Protection to Companies Ltd. (PROMEDICA) is a for-profit Brazilian HMO. PROMEDICA adopted postpartum/post-abortion family planning as the result of an OR project. The project examined the costs and benefits of providing postpartum/post-abortion IUDs and other temporary methods. Postpartum IUD acceptors used an average of one app ointment less during the first six months after delivery, compared to interval IUD acceptors. Post-abortion clients saved two 
visits. The project calculated family planning costs and savings in terms of services that were either used or prevented. PROMEDICA estimated that it prevented one pregnancy-related hospital stay for every 17 patients who accepted a temporary family planning method within the first six months postpartum. Finally, it compared the cost of providing services to 17 family planning acceptors with the cost of one patient admitted to the hospital for pregnancy. The cost-benefit relationship was 2.8 to 1 . In the context of a for-profit health care provider, family planning costs can be more than compensated by the savings from reducing other costs. (PROMEDICA)

\section{For-profitgroups may also offer family planning if the service provides them with a market advantage over competitors.}

n Prepaid health care organizations in Peru sell maternity packages which typically include prenatal and postnatal visits and delivery but not family planning. MEDICSA, a Lima-based HMO, tested the demand for postpartum family planning. During 13 months, MEDICSA offered all maternity patients postpartum family planning free of charge. All women delivering during the period accepted a method postp artum, over $80 \%$ the IUD (a \$35-50 interval service). As a result of the OR, MEDICSA added postpartum family planning to its maternity package at no additional cost to the client. The company was able to do this because of the low cost of providing postpartum IUD services. (MEDICSA)

\section{Some self-sustaining senice delivery organizations will add family planning if they are provided with technical assistance. Others fear that adding family planning will cause trouble with communities and religious groups They can often be induced to add family planning as part of a broader program of reproductive health services}

n AGROSALUD is a non-profit Guatemalan HMO serving over 25,000 agricultural workers. AGROSALUD was interested in adding family planning but was uncertain how to proceed. INOPAL provided technical assistance including provider training, supervision, Management Information Sciences (MIS), and evaluation. The TA resulted in AGROSALUD implementing CBD (pills and condoms) and clinical services (IUD, male and female sterilization). (AGROSALUD)

$\mathrm{n}$ In Honduras, many local and international organizations (such as CARE, Save the Children, Foster Parents Plan, and Meals for Millions) recognized the need for family planning but were reluctant to provide services for fear of a negative response from communities and religious groups. Instead of concentrating solely on family planning, INOPAL provided technical assistance in implementing rep roductive health services that also included breastfeeding promotion and cancer prevention. The organizations were not criticized and most went on to establish services, which increased the number of rural family planning/rep roductive health workers by $118 \%$, to a total of 2,600 . 


\section{B. S PECIAL POPULATIONS}

A special population is any group that faces exceptional barriers to receiving services. Common barriers in Latin America include lack of services when needed (a barrier for postpartum and post-abortion women); unavailability of desired methods (barriers for men and rural populations); and linguistic, cultural, gender, and age differences between clients and providers (barriers for indigenous groups, men, and adolescents).

\section{n ADOLESCENTS}

Lack of knowledge is an important barier to successful family planning use among sexually active adolescents. INOPAL supported family life education courses that included information on sexuality and contraception. These courses were found to have a long-term impact on knowledge of family planning methods. Evidence also suggested that sex education did not increase adolescent sexual behavior.

n Courses can increase contraceptive knowledge among adolescents. A family life education course tested by Instituto Mexicano de Investigación de la Familia y Población (IMIFAP) in 88 Mexican secondary schools increased the proportion of students who could name at least one contraceptive method from $40 \%$ to $80 \%$. Experimental group students who received the course were no more likely to become sexually active than controls who did not take the course. However, sexually active experimental group students were more likely to use contraceptives than sexually active controls. (IMIFAP) (See IMIFAP box.)

n INOPAL II conducted a follow-up study of adolescents who had participated in sex education classes offered as part of an INOPAL I OR project with Prosuperación Familiar Neoleneses (PSFN) of Monterrey, Mexico. Five years after taking the course, PSFN graduates had significantly higher family planning knowledge than a group of controls who had not received a course. The group that had taken the course was no more likely than those who had not taken a course to have had sexual relations in the month prior to the interview. (PSFN)

Table 5

Comparison of family planning knowledge levels and sexual activity: adolescents who received and did not receive PSFN sex education course

\begin{tabular}{||l|c|c||}
\hline INDICATOR & $\begin{array}{c}\text { ADOLESCENTS } \\
\text { TAKING } \\
\text { COURSE }\end{array}$ & $\begin{array}{c}\text { ADOLESCENTS } \\
\text { NOT TAKING } \\
\text { COURSE }\end{array}$ \\
\hline \hline $\begin{array}{l}\% \text { knowing 3+ family planning } \\
\text { methods }\end{array}$ & $68.1 \%$ & $40.7 \%$ \\
\hline $\begin{array}{l}\% \text { sexually active in month } \\
\text { prior to interview }\end{array}$ & $29.3 \%$ & $27.9 \%$ \\
\hline
\end{tabular}


Family life education courses are acceptable to LAC parents, teachers, and students.

$\mathrm{n}$ Figure 6 shows the responses of parents, teachers, and students to a question about including the family life "Adolescence and Development" course, which included information on family planning and reproduction, in the curriculum of Mexican National Secondary Schools. Positive feedback from students, parents, and teachers helped the Mexican Ministry of Education decide to incorporate large parts of the course in the National Secondary School Curriculum. The State of Coahuila made the entire course a requirement in its public schools. The IMIFAP course is also the most used family life curriculum in Mexican private schools. With funding from other donors, IMIFAP conducted training of trainers in other Latin American countries. (IMIFAP) (See Figure 6.)

\section{Figure 6 \\ IMIFAP, Mexico \\ Opinions about the Adolescence and Development Course}

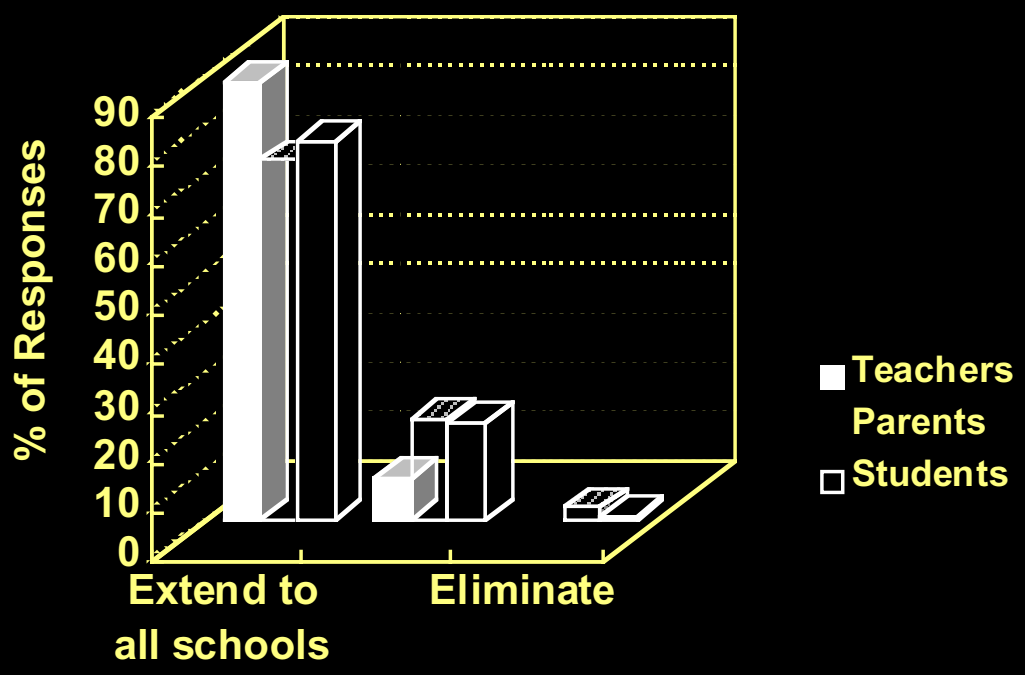

OPINION ABOUT

COURSE 


\section{n MEN}

INOPAL research suggests that men will participate in family planning if provided the op portunity in a way that is sensitive to their special needs. In Latin America, family planning has traditionally been integrated with maternal and child health services, which are not accessible to men. INOPAL projects found a large demand for male methods when services were offered in ways and times that were accep table and convenient to men.

\section{Providing family planning services outside of a maternal and child health setting can increase male participation.}

$\mathrm{n}$ In Iquitos, Peru, the Ministry of Health offered family planning in two hospitals in morning clinics also offering maternal and child health services. VECINOS PERU assisted the Ministry in testing the effectiveness of afternoon clinics dedicated exclusively to family planning. One impact was an increase in the number of male users. In the two integrated morning clinics, $2-6 \%$ of family planning clients were men. In contrast, $14-24 \%$ of clients at the afternoon clinics, devoted exclusively to family planning, were men (VECINOS PERU II). A similar pattern of results was obtained during an INOPAL I study of afternoon clinics in the mountain cities of Ay acucho and Huancavelica. (VECINOS PERU I)

n Male workers can improve the family planning knowledge and attitudes of men. The Ministry of Health in Mexico used men to promote family planning among predominantly male organizations like peasant unions and community councils. Family planning knowledge increases of 25-35\% were registered in communities with male promoters, and the number of men approving of male or female sterilization as contraceptive methods increased by $17-26 \%$. The Ministry of Health adopted the strategy in heavily rural states. (Dessarrollo e Investigación de la Planificación Familiar, A.C.)

\section{There appears to be a large potential demand for vasectomy in Latin America.}

$\mathrm{n}$ In Mexico, a survey of Instituto Mexicano de Seguro Social (IMSS) clients found that nearly one-third of married men (31\%) and one-fifth of married women of reproductive age not already using sterilization would probably choose vasectomy as their first choice when they achieved their desired family size. (IMSS)

To assist in services planning, INOPAL II constructed a composite profile of a Latin American vasectomy acceptor from surveys and focus groups conducted during INOPAL I and INOPAL II. (See Figure 7.)

OR projects also studied information-seeking behaviors during vasectomy decision- making and found opportunities for programs to intervene in all stages of the process. (See Figure 8.) 
Women play important roles in making their partners aware of vasectomy, and they exercise the most influence over their partner's decision to adopt the method. Women attending family planning clinics and perinatal services should receive orientation and written materials about the method.

Because potential users seek out vasectomized men for information, recniting satisfied users as volunteer promoters may be an effective clinic-based vasectomy promotional activity.

$\mathrm{n}$ The IMSS compared two in-clinic vasectomy promotion strategies. In the first intervention, newly vasectomized volunteers were provided with brief training in making referrals and with vasectomy information materials to pass out among their friends. In the second intervention, promotional videos were shown to nonvasectomy clients in waiting rooms. One clinic served as the control. As shown in Figure 9, using volunteer promoters appears to have resulted in a larger relative increase in vasectomy acceptance (13\% vs. $7 \%$ in the control and $8 \%$ in the video intervention groups.)

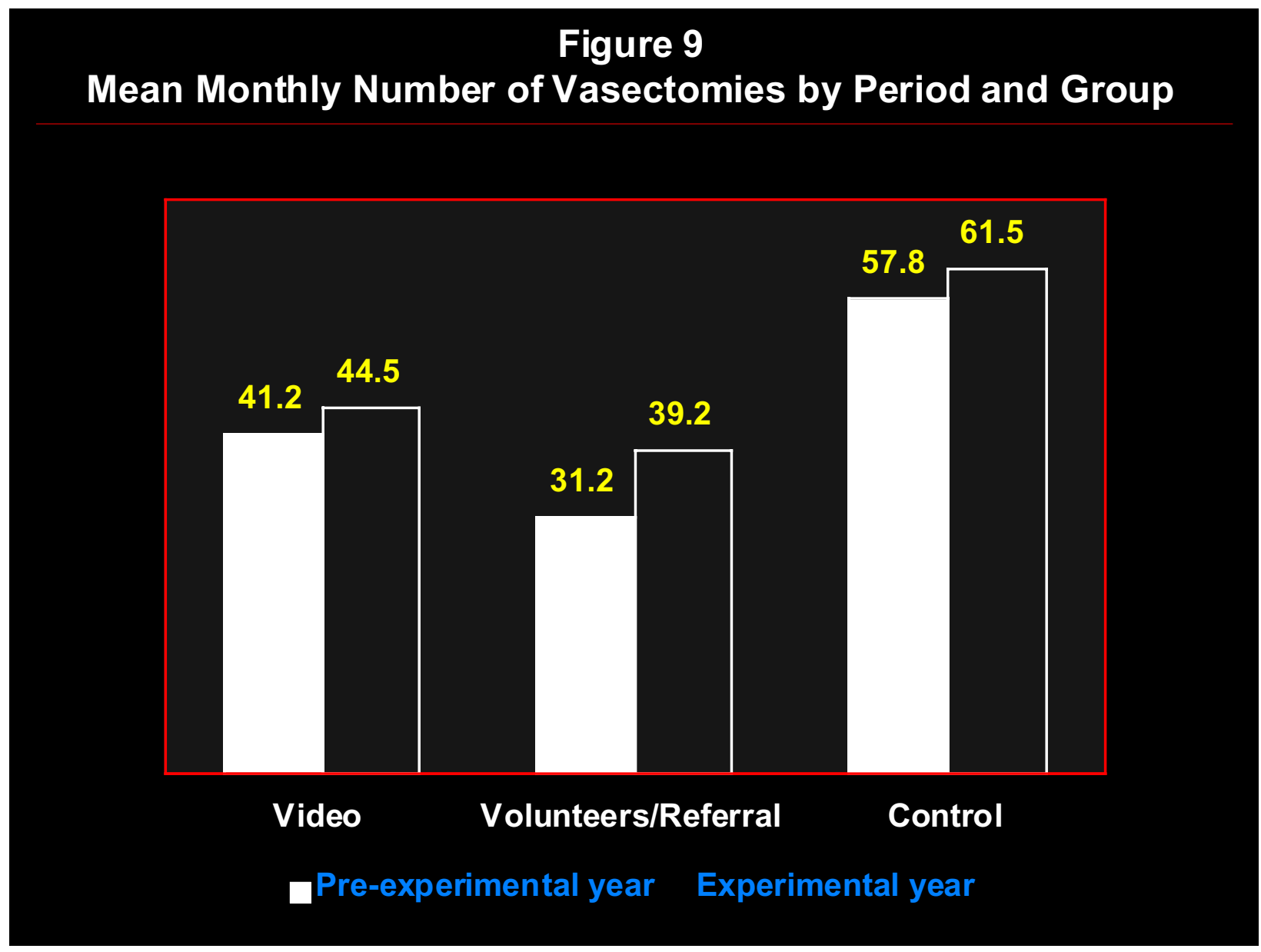


The satisfied-user strategy was adopted by IMSS and is used in over 100 clinics in 13 Mexican states. IMSS also decided to adopt the somewhat less effective strategy of showing vasectomy videos in clinic waiting rooms. (Academia M exicana de Investigación en Demografía) (See Figure 9.)

\section{n POS TPARTUM WOMEN}

In Latin America nearly 43\% of all conceptions occur within 15 months of a previous birth. Early conception is a leading cause of high-risk pregnancy and maternal and child morbidity and mortality in the region. Since most women in Latin America now deliver in health facilities, hospital-based postpartum family planning programs have the potential to reduce the number of early, high-risk pregnancies. In INOPAL II sub-projects, postpartum services included prenatal contraceptive information, the offer of ap prop riate family planning methods prior to hospital discharge, and, in some projects, the offer of contraceptives at 40-day and subsequent postpartum visits.

\section{Postpartum family planning services are popular with Latin American women.}

n A survey of women delivering in a large Lima hospital indicated that over $40 \%$ wished to receive a family planning method prior to discharge. Figure 10 shows the desired timing of contraceptive initiation among new mothers. (PROFAMILIA/Instituto Peruano de Seguridad Social). (See Figure 10.)

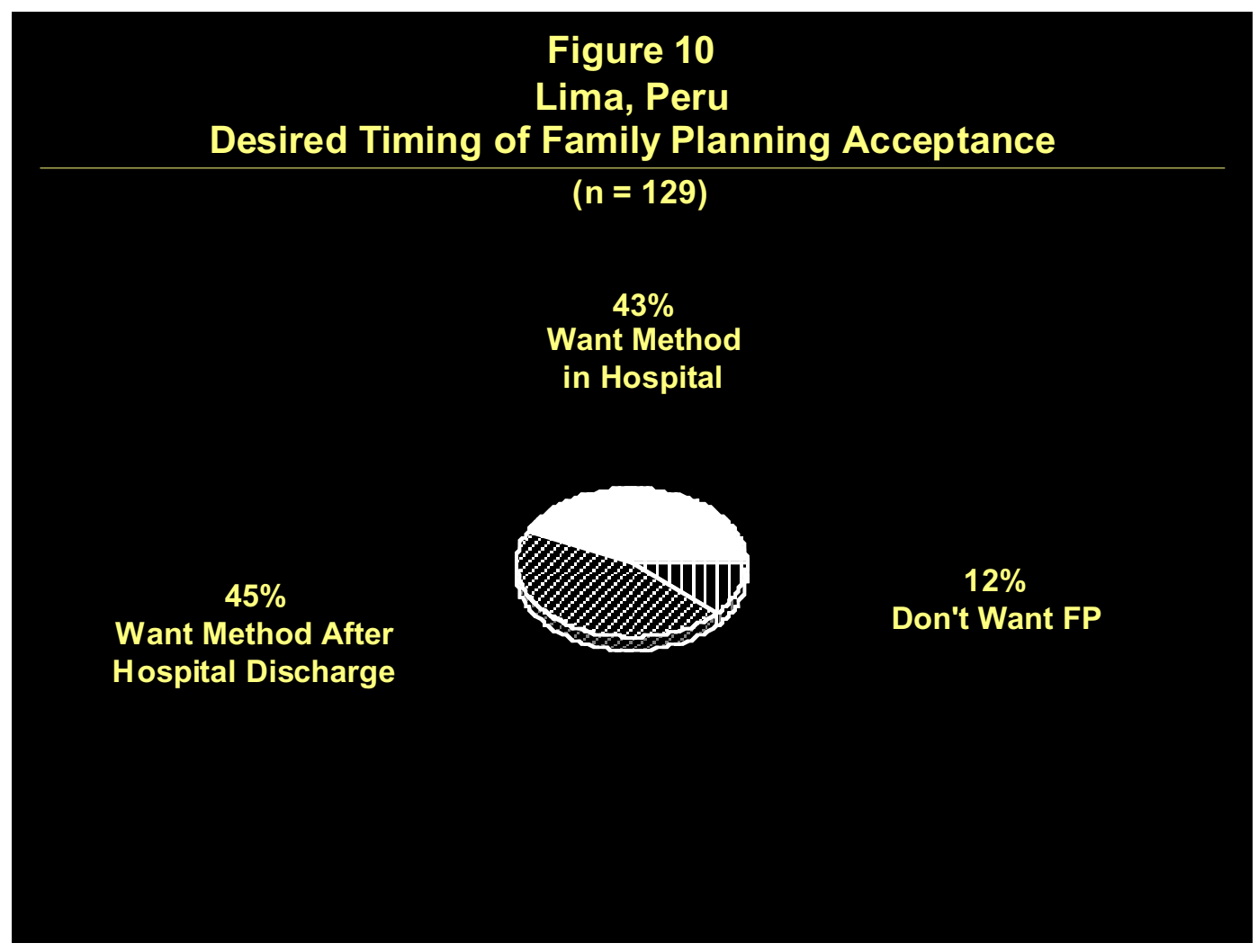


$\mathrm{n}$ Acceptance rates vary by setting and variety of contraceptives offered, but important numbers of new acceptors are recruited by most postpartum programs. In a Brazilian HMO, postpartum acceptance of all methods within six months of childbirth reached $68 \%$. In the same study postpartum, in-hospital IUD acceptance reached almost 33\%. In public hospitals in Peru, IUD acceptance ranged from 7-22\%, depending on the hospital. The Brazilian HMO, PROMEDICA, the Peruvian social security system, and the Ministry of Health adopted postpartum family planning sy stem-wide.

$\mathrm{n}$ In a Honduran Social Security hospital where a variety of methods was offered at two points in time (at discharge and at a 40-day clinic integrating services for the mother and the infant), overall acceptance was $45 \%$ (IHSS). Figure 11 suggests the advantages of offering postpartum family planning at more than one point in time. (See Figure 11.)

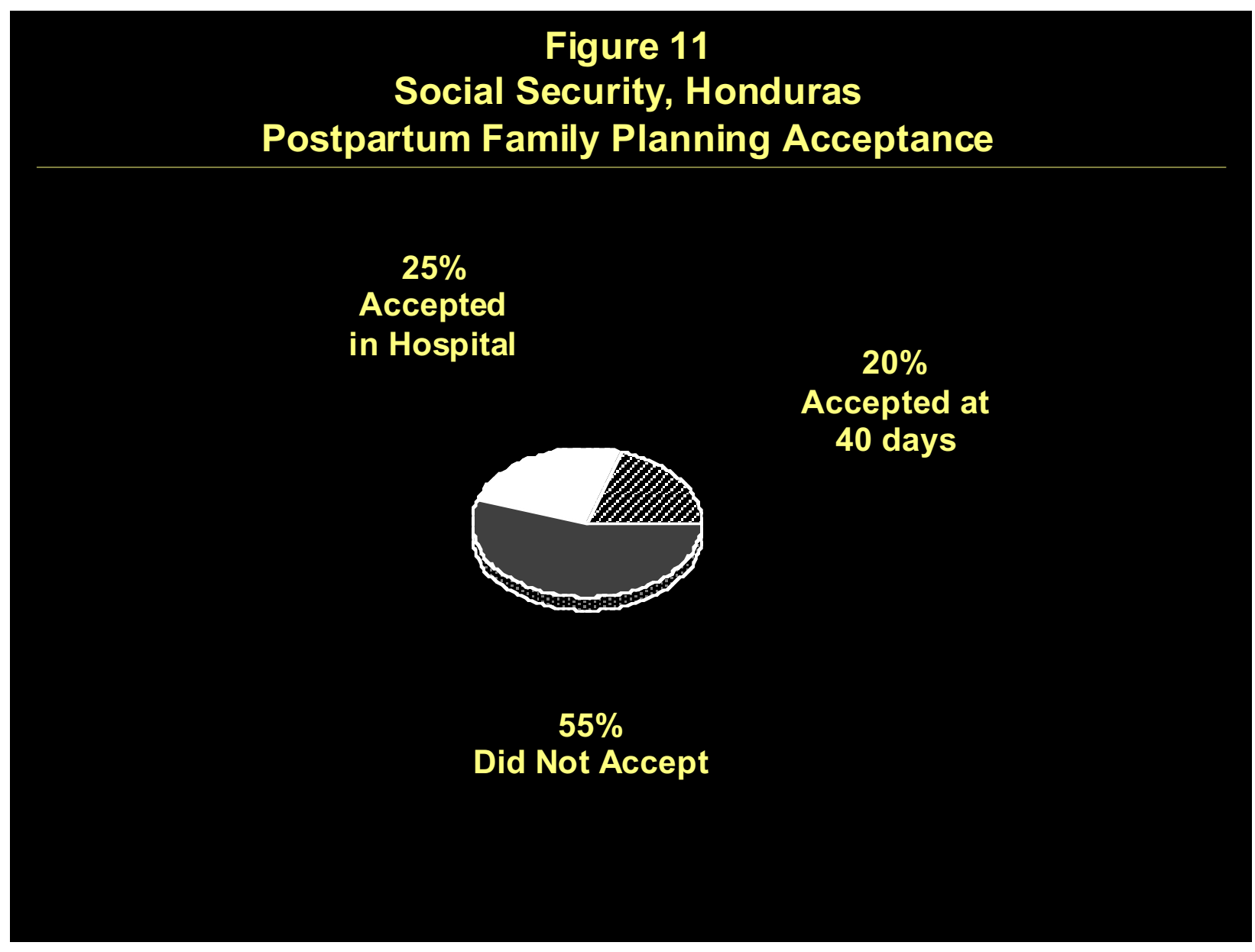

n A 40-day postpartum clinic established by a Honduran Social Security hospital was successful both in increasing the rate of return to postpartum services and in increasing postpartum contraceptive use. The proportion of women who returned for a checkup at 40 days postpartum increased from about $15 \%$ to almost $40 \%$. Only $19 \%$ of the mothers arriving at the 40 -day clinic were already using a method, and nearly 61\% accepted a method during their visit-mainly mini-pills (51\%) and IUDs (41\%). The Social Security sy stem now offers postpartum family planning in-hospital and at a 40-day 
clinic to all subscribers and their dependents. (IHSS)

In existing programs, provider participation, rather than client interest, appears to be the major determinant of postpartum family planning acceptance, implying that managers need to develop techniques to maximize provider participation in postpartum programs.

$\mathrm{n}$ In both INOPAL I and INOPAL II postpartum projects, client acceptance depended on the number of providers in an organization who participated in the project. PROMEDICA was able to stimulate greater participation by physicians in the program by sending reminder letters stating that it was institutional policy to provide postpartum IUD insertions (unless medically contraindicated) for all women requesting the service. The letters also gave phy sicians feedback on the number and proportion of their maternity patients receiving IUD insertions. Figure 12 shows the impact on IUD acceptance after PROMEDICA management began sending doctors reminder letters. (See Figure 12.)

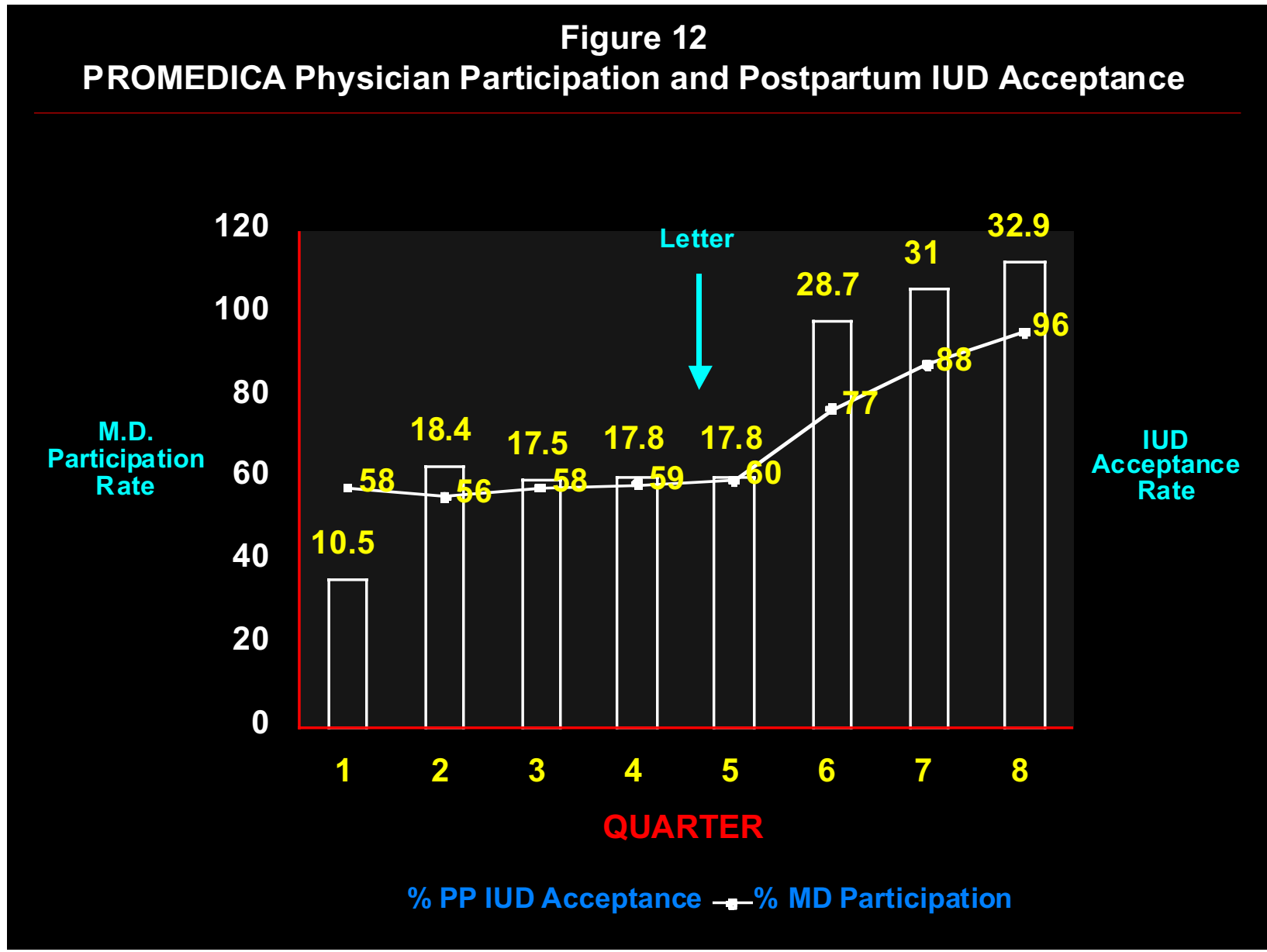

$\mathrm{n}$ Although as many as $40 \%$ of women delivering in large Lima hospitals wished to receive an IUD prior to leaving, only about $7 \%$ actually obtained the device. In Peru, nurse-midwives deliver most babies born in public sector facilities, but in the Lima hospitals that receive referrals of high- 
reproductive-risk women, norms restrict postpartum IUD insertion to physicians. Limited contacts between phy sicians and normal-risk patients reduced method availability for women whose births were attended by midwives. In hospitals that permitted nurse-midwife insertion, postpartum IUD acceptance rates were higher, ranging from $17-22 \%$, depending on the hospital. (PROFAM ILIA I)

\section{Postpartum contraceptive use reduces the number of early pregnancies.}

n PROMEDICA compared pregnancies among two groups of nonsterilized women: those accepting a temporary method postpartum and those not accepting a method. Within 21 months of their last birth, $13 \%$ of nonacceptors experienced a pregnancy-related hospitalization in PROMEDICA, compared to $5 \%$ of postpartum acceptors. (PROMEDICA)

\section{Postpartum contraceptive services are cost-effective compared to interval sevices and are cost-} beneficial to the institution providing them.

$\mathrm{n}$ The Peruvian Social Security Institute (IPSS) estimated that a postpartum IUD insertion costs less than $40 \%$ an interval IUD insertion. PROMEDICA found that every $\$ 1$ invested in postpartum family planning services saved the company $\$ 2.80$ in pregnancy-related services. PROMEDICA adopted postpartum family planning in all its hospitals. (PROFAMILIA/IPSS and PROMEDICA) (See IPSS box.)

Integrated postpartum services may be feasible in mral areas, even where most women deliver at home.

n Postpartum family planning programs are usually restricted to hospitals. However, in rural Haiti, up to $90 \%$ of women deliver at home. Comité Bienfaisance de Pignon (CBP) provides health services to a rural population. CBP added a postpartum service consisting of paid, trained traditional birth attendants (TBAs) who bring women for prenatal and postpartum services including check-ups for mother and baby, breastfeeding counseling, vaccination, and family planning. TBAs managed to recruit $60 \%$ of women delivering in the area during a four-month period, $17 \%$ of whom accepted a family planning method at the postpartum clinic (another $17 \%$ had accepted a method prior to the visit from a community-based distributor). Women accepting during the postpartum visit were more likely to receive a clinical method (sterilization, NORPLANT, DMPA) and less likely to receive condoms, tablets, and pills than postpartum women accepting from community-based distributors. CBP extended its integrated rural perinatal program from an area serving 40,000 to one serving ap proximately 100,000 people. (CBP)

Programs offering the Lactation Amenorrhea Method can increase duration of exclusive breastfeeding to the benefit of children as well as mothers. 
$\mathrm{n}$ A program in rural Honduras increased the median duration of exclusive breastfeeding among experimental-group women from 1.2 to 3.0 months while median duration among controls remained at 1.2 months (Asociación de Lactancia Materna). CARE/Honduras more than doubled the percentage of mothers exclusively breastfeeding at four months, from $40 \%$ to $87 \%$ (CARE/Honduras). After completion of the rural projects and dissemination of results, a total of 18 NGOs and the Ministry of Health received technical assistance from AHLACMA to add breastfeeding promotion to their health services.

n In urban Brazil, an LAM promotion project conducted by IMIP resulted in 13\% of women using LAM as a contraceptive at three months postpartum. A great advantage of the method was its impact on child health. The infants of women in the group offered LAM had significantly lower morbidity and hospitalization rates than children of control mothers. No significant between-group differences were found in pregnancy rates at 12 months postpartum. IMIP added LAM promotion to its routine services for all postpartum women. (IMIP)

Table 6

Comparison of selected 12-month morbidity rates among children whose mothers used LAM and controls who did not

\begin{tabular}{|c|c|c||}
\hline PROBLEM & $\begin{array}{c}\text { CHILDREN OF LAM } \\
\text { USERS } \\
\text { N }=215\end{array}$ & $\begin{array}{c}\text { CHILDREN OF } \\
\text { CONTROLS } \\
\text { N }=350\end{array}$ \\
\hline \hline HIGH RESPIRATORY INFECTION & 49.8 & 74.1 \\
\hline OTITIS/EAR PAIN & 1.9 & 13.2 \\
\hline HOSPITALIZATION & 7.1 & 18.1 \\
\hline NO REPORTED MORBIDITY & 27.9 & 14.4 \\
\hline
\end{tabular}

\section{n RURAL POPULATIONS}

Lack of access to services is the greatest family planning problem confronting rural populations in Latin America. No program has yet developed a fully successful service delivery model able to overcome the high costs imposed by dispersed populations. An additional concern is increasing the number of family planning methods available to rural women and men.

Training para- and non-professional providess remains the key to increased method availability in mral Latin America.

$\mathrm{n}$ In rural Honduras, CARE started a CBD program with a community education component. Contraceptive prevalence increased from 13\% to 25\%. Training Ministry of Health rural health post staff in IUD insertion increased mean monthly insertions from two to 20 . The training curriculum 
developed for the project was adopted by other agencies in Honduras. (CARE/Honduras)

$\mathrm{n}$ In Bolivia, INOPAL trained auxiliary nurses in rural areas to insert IUDs and take pap smears. IUD training costs for auxiliaries were initially higher than for professionals. However, auxiliaries remain in rural communities longer than phy sicians. Consequently, long-term cost-effectiveness of IUD training for auxiliaries may compare favorably with training phy sicians. (Child and Community Health Project)

$\mathrm{n}$ A study in rural Peru used a simulated client methodology to leam if nonprofessional volunteer health workers could successfully provide Depo-Provera (DMPA). The study demonstrated that volunteers could provide as high quality DMPA services as para-professional community health workers, many with several years of experience. (INANDEP/MOH)

n Para-professionals are capable of effective client-targeting activities in rural areas. In Queretero, Mexico, the Ministry of Health experimented with a segmentation and targeting approach to identify and target women in rural communities with unmet need for family planning. Promoters conducted a census of women in rural communities then targeted high-p arity women, exceptionally young mothers, and women with an unmet need for contraception. Depending on the community, contraceptive acceptance among targeted women ranged from $38-65 \%$. Targeting was included statewide among the routine activities of rural health workers. (Desarrollo e Investigación de la Planificación Familiar, A.C.)

n In Guatemala, Ministry of Health family planning supervisors are required to visit 100 health centers and posts twice a year. The schedule provided little or no time for training, problem solving, or motivational activities in rural areas. The Ministry tested two strategies to improve supervision: (1) indirect supervision, in which one of the two annual visits to each unit was replaced by a one-day meeting at the district level with the supervisor; and (2) self-assessment, in which one supervised visit was replaced by a two-day workshop where participants filled out self-assessment checklists identify ing quality-of-care problems and made a plan to solve identified problems during the following months.

The two experimental group s were compared to a control group that received traditional supervision. In both alternative strategies, supervisors were able to reach a larger proportion of health providers than control supervisors. Cost per provider supervised was lower in the two experimental groups. Supervisors were able to supervise ap proximately $99 \%$ of all posts under the self-assessment strategy at a cost per post of $\$ 114$. Group supervision resulted in $86 \%$ of posts being supervised at a cost per post of $\$ 97$. The traditional system succeeded in supervising only $60 \%$ of posts at $\$ 118$ per outlet. The Ministry adopted supervision based on provider self-assessment. (FPU/Guatemala)

\section{n INDIGENOUS GROUPS}

Indigenous groups make up a large proportion of unmet need for family planning in many Latin American countries including Bolivia, Ecuador, Guatemala, M exico, and Peru. Organizations wishing to provide family planning services to indigenous populations must overcome a double set of barriers: those imposed by cultural differences between clients and providers and those imposed by rural 
location.

Contraceptive use tends to be low in indigenous communities butpotential demand appears high. Misinformation about family planning is common, and services are often not delivered in a culturally appropriate manner.

$n$ An OR study conducted by CARE/Bolivia in the indigenous area of Tarija found that use of modern contraceptives was only $7 \%$ but that $80 \%$ of men and women aged $15-44$ wanted to use a modern method. (CARE/Bolivia)

n Like their rural sisters, most urban Aymara women in Bolivia want to regulate their fertility. However, suspicion of modern medicine and modern practitioners is quite high. Consequently, most women used traditional methods. (John Snow, Inc.)

$\mathrm{n}$ Among the rural indigenous population in Guatemala contraceptive prevalence is less than $5 \%$ for modern methods. Despite low levels of contraceptive use, previous studies have shown a large unmet need for family planning. Service-delivery strategies have focused largely on women, but men in Guatemala most often make family decisions, and they desire large families.

A study investigated the family planning knowledge, attitudes, and behaviors of men in El Quiché, a poor rural department in Guatemala. Focus groups and in-depth interviews confirmed that men believe they should make the decisions regarding reproduction. Most respondents clearly identified the advantages of birth spacing. Their responses, however, demonstrated widespread misinformation about sexuality and reproduction. Most men could identify contraceptives, but knowledge of their use was limited. Only a small minority cited religious beliefs as a reason for nonuse of contraception. Most men were very interested in receiving information about contraception and reproductive health. (APROFAM)

\section{QUAUTY OF CARE}

INOPAL I pioneered quality-of-care activities in Latin America. INOPAL II (1) studied user perceptions of quality; (2) measured quality; (3) operationalized quality-of-care concepts to actually improve family planning services; and (4) examined the impact of quality improvements on contraceptive use.

\section{n US ER PERCEPTIONS OF QUAUTY}

User perceptions of quality are often very different from the quality perceptions of donors and providers. Incorporating user perceptions into donor agency definitions may result in greater services utilization and client satisfaction.

n Users identify amenities such as treatment by physicians, short waits for service, and pleasant surrounding as quality of care. (MEXFAM) 
n Quality and price are two of the most imp ortant factors in choosing a family planning provider. In Ecuador, a survey of potential users showed that women associated higher price with higher quality. Private phy sicians were seen as offering the highest quality at the highest price, and the public sector as offering the lowest quality at the lowest price. Private, nonprofit organizations were perceived as intermediate on the quality-price scale. While users are concerned with both price and quality, some chose services based on price while others chose services based on perceptions of quality. A hypothesis worth pursuing by NGO family planning organizations is that providers can gain market share by offering higher quality at the same price as competitors or the same quality at a lower price. (APROFE) (See Figure 13.)

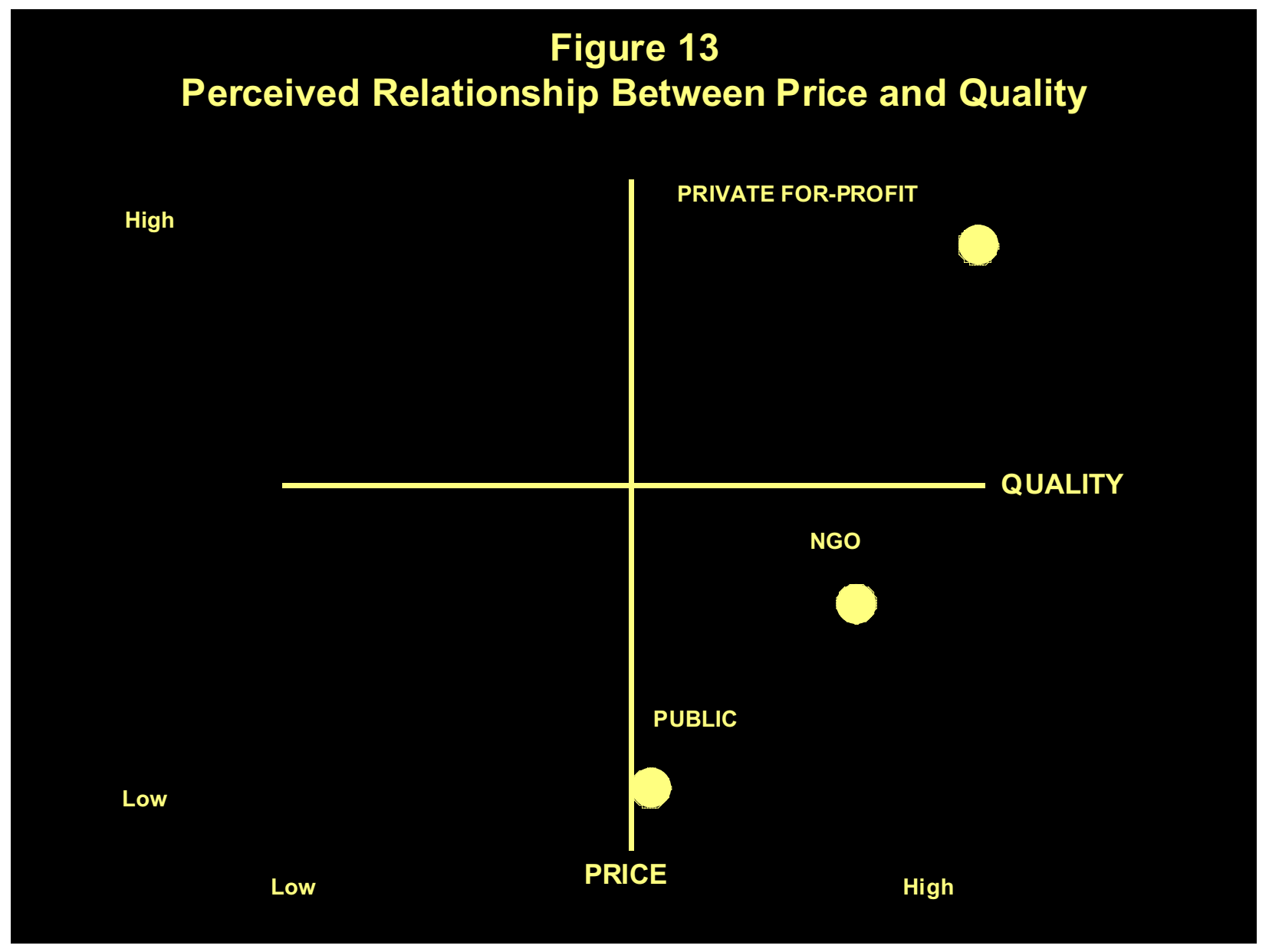




\section{n MEASUREMENT OF QUAUTY}

Measuring quality is a precondition to determining if it can be controlled by managers and if quality has an impact on contraceptive use. INOPAL developed a standardized test of community-based distributor family planning knowledge to measure provider technical competence, and a simulated (mystery) client methodology to study the quality of the client/provider interaction. INOPAL also produced Spanish and Portuguese instruments for situation analy sis.

\section{There is a need for new community-based distributor training techniques to improve the quality of the services they provide.}

$\mathrm{n}$ A large proportion of $\mathrm{CBD}$ and community health volunteers display a level of family planning knowledge on a standardized test that is no better than chance (the number of correct responses to multiple choice questions expected if the "correct" alternative was selected at random), suggesting that they offer inadequate quality of care. However, as many as $20 \%$ of distributors have knowledge levels equal to those of the majority of professionals (educators, nurses, phy sicians) from the same agencies. In Peru, it was found that PVO distributors had higher contraceptive knowledge than Ministry of Health community health volunteers who had received family planning training at some time in the past. Figure 14 shows standardized test scores from Peru for three groups of family planning workers. (Asociación Benefica PRISMA [Proy ectos en Informatica Salud, Medicina y Agricultura]

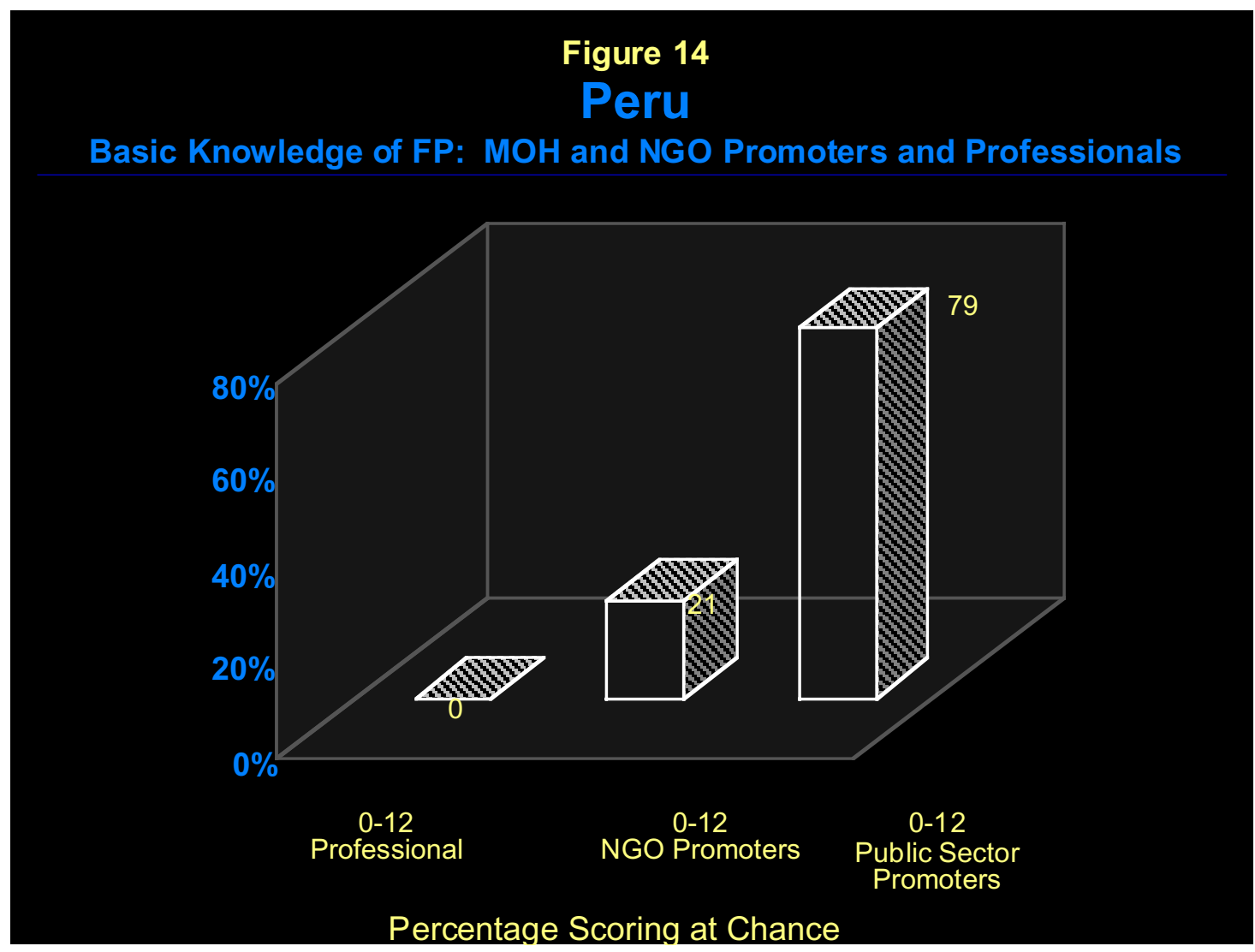


The highest levels of family planning knowledge on the standardized test were obtained by paid, fulltime Haitian CBD workers (only about $8 \%$ scored no better than chance). Part-time volunteer CBD workers in NGO programs in Peru and Ecuador had intermediate knowledge levels (about 15-25\%, depending on the agency, scoring no better than chance). The worst performance on the standardized test was obtained by rural $\mathrm{MOH}$ community health workers in Peru, almost $80 \%$ of whom scored no better than chance. The health workers had many duties other than family planning and did not usually distribute contraceptives. These results suggest the importance of practice in reinforcing knowledge gained during training. From both quality and cost perspectives, it may be better not to train paraprofessionals who do not distribute contraceptives. (See Figure 14.)

Increased evaluation of training and actual provider performance is needed to improve CBD quality of care.

$\mathrm{n}$ Wider use of the standardized test would permit trainers to focus on individual distributors with defective knowledge while avoiding an investment in retraining those with adequate knowledge. The standardized test would also permit comparisons of provider knowledge across programs, countries, and training courses.

$\mathrm{n}$ The use of simulated clients has demonstrated that regardless of technical competence, a large proportion of community-based distributors do not communicate information necessary to successful method use. Providers are especially reluctant to talk about potential side effects because they are afraid of losing family planning clients. Increasing information about side effects might improve method continuation. (INANDEP)

\section{n IMPROVEMENT OF QUAUTY}

INOPAL II has experimented with Continuous Quality Improvement (CQI) and job aids such as expert systems for providers to improve family planning program quality.

CQI can be successfully applied in family planning organizations: it leads to improvements in many aspects of program operations.

n In CQI, quality teams identify and solve problems. Figure 15 shows the proportion of identified problems solved by CQI teams in Guatemala Ministry of Health clinics. Table 7 is a partial list of improvements made in MEXFAM clinics by CQI teams. (See Figure 15.) 


\section{Figure 15 \\ MOH, Guatemala \\ Quality Improvement Time}

Percent of Problems Solved Within Three Months of Identification

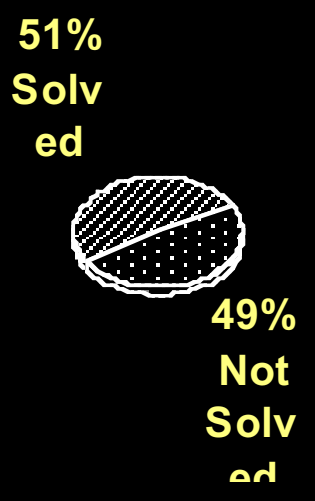


Table 7

MEXFAM: Mexico

Selected changes produced by CQI teams

\begin{tabular}{||l|l||}
\hline \multicolumn{1}{||c||}{ TEAM } & \multicolumn{1}{c||}{ IMPROVEMENTS } \\
\hline \hline Catemaco Clinic & $\begin{array}{l}\text { Reduced time for processing lab tests. All results now given on } \\
\text { same day. Patients given appointments to pick up results so they } \\
\text { do not have to wait at clinic for entire day. }\end{array}$ \\
\hline $\begin{array}{l}\text { Cuajimalpa Community } \\
\text { Phy sicians Program }\end{array}$ & $\begin{array}{l}\text { Use of clinical history forms introduced. App earance of examining } \\
\text { and waiting rooms improved with pictures, reading materials, signs, } \\
\text { and posters. }\end{array}$ \\
\hline La Villa Clinic & $\begin{array}{l}\text { Survey ed clients. Waiting time was greatest complaint. Team } \\
\text { study ing way s to reduce waitingtime. Services started earlier in } \\
\text { the day to make them more convenient to patients. Other quality } \\
\text { improvements: examiningtable sheets changed after every client, } \\
\text { use of disposable gloves, pediatrics service added. Waiting room } \\
\text { improved by providing water carafes and TV. }\end{array}$ \\
\hline MEXFAM Warehouse & $\begin{array}{l}\text { Reduced average time to fill supply orders from 20 to } \\
\text { 12 days. }\end{array}$ \\
\hline $\begin{array}{l}\text { Nezahualcoyotl } \\
\text { Clinic }\end{array}$ & $\begin{array}{l}\text { Remodeled clinic; waiting room furnished with magazines, TV, } \\
\text { plants, and pictures. Decreased underreporting of clients by } \\
\text { changing data-gathering rocedures. }\end{array}$ \\
\hline \hline
\end{tabular}

$n$ The MEXFAM experience demonstrates that the CQI methodology can improve access, technical quality, and amenities. CQI also produced improvements in program efficiency. The system permitted MEXFAM's accounting dep artment to reduce the time needed to produce rep orts, increased the income of some clinics, and increased CBD program recruitment and efficiency by substituting group talks in day-care centers for individual home visiting of potential clients. (MEXFAM)

\section{Use of an interactive counseling tool can improve health workerperformance during the client-provider interaction.}

$n$ INOPAL developed the $\mathrm{ABC}$ as a response to high training costs and low levels of rural $\mathrm{CBD}$ provider knowledge. The $\mathrm{ABC}$ is a decision tree that guides a worker through the client-provider interaction with both new and returning clients. It covers pills, Depo-Provera, and barrier methods. Training in the $\mathrm{ABC}$ takes less than a day, compared to three day s for the traditional course. In three experiments, distributors who used the $\mathrm{ABC}$ provided as high or higher quality services (as measured by scores derived from checklists filled out by simulated clients) than distributors trained in more costly and time-consuming traditional courses. 
Table 8

Results from three studies of the $\mathrm{ABC}$

\begin{tabular}{|c|c|c|c|}
\hline $\begin{array}{l}\text { INSTITUTION/ } \\
\text { LOCATION }\end{array}$ & $\begin{array}{l}\text { PROGRAM } \\
\text { SETTING }\end{array}$ & PROVIDERS & RESULTS \\
\hline $\begin{array}{l}\text { CEPEP: } \\
12 \text { districts in } \\
\text { Paraguay, } \\
1992-1993\end{array}$ & $\begin{array}{l}\text { Rural and } \\
\text { village }\end{array}$ & $\begin{array}{l}\text { Volunteer } \\
\text { community-based } \\
\text { distributors }\end{array}$ & $\begin{array}{l}\text { Providers who received a brief refresher } \\
\text { training with the } \mathrm{ABC} \text { p rovided higher } \\
\text { quality of care than those receiving } \\
\text { longer, traditional refresher course. } \\
\text { ABC training costs were only } 20 \% \text { of } \\
\text { the traditional course. }\end{array}$ \\
\hline $\begin{array}{l}\text { APROSAMI and } \\
\text { CENPROF: Callao } \\
\text { and Trujillo, Peru, } \\
\text { 1991-1992 }\end{array}$ & Urban slum & $\begin{array}{l}\text { Volunteer } \\
\text { community-based } \\
\text { distributors }\end{array}$ & $\begin{array}{l}\text { Providers who received training in the } \\
\text { use of the } A B C \text { in addition to normal } \\
\text { sup ervision provided higher quality of } \\
\text { care than providers who received only } \\
\text { normal supervision. }\end{array}$ \\
\hline $\begin{array}{l}\text { Ministry of Health } \\
\text { and CARE: } \\
\text { Puno, Piura, and } \\
\text { Tumbes, Peru, } \\
1993\end{array}$ & $\begin{array}{l}\text { Rural and } \\
\text { village }\end{array}$ & $\begin{array}{l}\text { Para-professional } \\
\text { health workers } \\
\text { and community } \\
\text { health volunteers }\end{array}$ & $\begin{array}{l}\text { Quality of care provided by workers } \\
\text { who received ABC training was higher } \\
\text { than quality of care provided by those } \\
\text { who received training in the use of a } \\
\text { traditional health-workers' manual. } \\
\text { Most workers preferred the ABC, } \\
\text { say ing it was easier to use than the } \\
\text { manual. }\end{array}$ \\
\hline
\end{tabular}

\section{n IMPACT OF QUAUTY OF CARE ON METHOD US E}

A frequently encountered hypothesis is that quality-of-care improvements result in increased method use. INOPAL has examined the impact of quality of care on factors such as continuation, acceptance, and CYP. Results to date mostly do not support the hyp othesis of improved user outcomes.

INOPAL I conducted a single quality-of-care project. An experiment attempted to determine if improving providers' technical competence resulted in greater program continuation among pill users in a $\mathrm{CBD}$ program. Improvements in the technical competence of $\mathrm{CBD}$ providers did not result in longer program continuation among pill acceptors (INPPARES II). A possible explanation for the result is that improved provider knowledge by itself is not sufficient to improve outcomes, because providers may not pass on their knowledge to clients. The project led INOPAL to develop a simulated-client methodology to measure the quality of the client-provider interaction.

$\mathrm{n}$ In a secondary analysis of a study of Depo-Provera (DMPA) use in Peru, providers in two 
provinces were assigned quality-of-care scores based on simulated client interactions. The scores were correlated with client DMPA continuation. In one province, Piura, there was a very modest but statistically significant $r$ of $.19(\mathrm{p}<.01)$ between level of provider quality of care and length of continuation. In the second province, Puno, the correlation was not significant (INANDEP). Qualityof-care scores, continuation, and acceptance were all higher in Piura than in Puno. Thus it is possible that there is a quality threshold that must be crossed before quality affects use. Alternatively, both quality and continuation may be functions of demand for contraception. Greater demand results in more provider practice and familiarity with the service being provided. At the same time, higher demand may also signal a higher motivation by users to continue contraceptive use.

$\mathrm{n}$ In the Guatemala Ministry of Health supervisory exp eriment, the staff of one experimental group of clinics used a self-assessment strategy based on the AVSC COPE initiative where, with the aid of checklists, program staff identified service-delivery areas that needed improvement. A second intervention group received indirect supervision. Once a year they attended a 4-6 hour group meeting where supervisors discussed problems and lectured on topics such as reproductive risk, contraceptive technology, and quality of care. A control group received traditional individual supervisory visits. No statistically significant differences in CYP were observed among the three groups. (Guatemala, MOH)

n CQI quality improvements produced mixed results on indicators of method acceptance and use. For example, some MEXFAM clinics using CQI rep orted increased numbers of new acceptors while others did not. Also, different outcome indicators in the same clinics sometimes produced contrary results. For instance, in one clinic, the number of new acceptors increased after CQI improvements but the number of continuingusers declined. (MEXFAM)

INOPAL findings about the effect of quality of care on family planning use have been based mostly on correlational analysis or data obtained in demonstration projects (the INPPARES and Guatemala Ministry of Health studies being exceptions). Additional research on the relationship between quality and use needs to be conducted in the LAC region. For this research to have program relevance, specific interventions manipulable by managers must be tested, and access and other confounding factors (number of methods available, cost, frequency of staff turnover, level of demand, etc.) controlled. It is also important that the interventions used in the experiments be cost-effective and easily incorporable by large-scale family planning organizations. 


\section{DIFFUS ION OF THE IMIFAP PROJECT}

\begin{tabular}{|c|c|c|}
\hline INOPAL I S UPPORT & $\rightarrow$ & INOPAL II SUPPORT \\
\hline $\begin{array}{l}\text { IMIFAP develops the "Planning Your Life" } \\
\text { course, which includes sex education and } \\
\text { family planning. An experimental design } \\
\text { with intervention and control groups is used } \\
\text { to test the course in secondary schools. } \\
\text { Results show no increased sexual activity in } \\
\text { the exp erimental group, but greater } \\
\text { contraceptive use at first intercourse among } \\
\text { experimentals who become sexually active } \\
(1988-1989) \text {. }\end{array}$ & & $\begin{array}{l}\text { With INOPAL II TA, the Mexican } \\
\text { Ministry of Education (MOE) evaluates } \\
\text { "Planning Your Life" in } 144 \text { schools in } \\
25 \text { states. Positive effect on knowledge } \\
\text { shown. Op inion polls and focus groups } \\
\text { show strong supp ort by parents for } \\
\text { adding the course to the secondary } \\
\text { school curricula(1991-1992). }\end{array}$ \\
\hline$\downarrow$ & & $\downarrow$ \\
\hline OTHER S UPPORT & & OTHER S UPPORT \\
\hline $\begin{array}{l}\text { Funding obtained from several sources to } \\
\text { train Mexican teachers, health educators, and } \\
\text { others in the "Planning Your Life" course } \\
(1989-1995) .\end{array}$ & & $\begin{array}{l}\text { MOE contracts IM IFAP to adapt } \\
\text { "Planning Your Life" for inclusion into } \\
\text { existing primary and secondary school } \\
\text { courses. About } 50 \% \text { of the original } \\
\text { contents are included in the secondary } \\
\text { curriculum. The State of Coahuila adds } \\
\text { the course in its entirety to the } \\
\text { curriculum. The course is widely } \\
\text { adopted by private schools in Mexico } \\
(1992-1995) \text {. }\end{array}$ \\
\hline$\downarrow$ & & $\downarrow$ \\
\hline $\begin{array}{l}\text { Bergstrom Fund supports training of trainers } \\
\text { from nine Latin American countries in the } \\
\text { "Planning Your Life" curriculum } \\
(1993-1995) \text {. }\end{array}$ & & $\begin{array}{l}\text { IM IFAP conducts a Gallup poll (1993) } \\
\text { indicating public support for sex and } \\
\text { family planning education. The M exican } \\
\text { congress passes a law requiring schools } \\
\text { to create "consciousness about. . family } \\
\text { planning and responsible parenthood." } \\
\text { (1993) A video based on the course is } \\
\text { shown repeatedly on TV (1993-1995). }\end{array}$ \\
\hline
\end{tabular}




\section{DIFFUS ION OF THE IPS S PROJECT}

\begin{tabular}{|c|c|c|}
\hline INOPAL I S UPPORT & $\rightarrow$ & INOPAL II SUPPORT \\
\hline $\begin{array}{l}\text { IPSS conducts an exp eriment in two wards of } \\
\text { a single hospital to determine the } \\
\text { effectiveness and cost-effectiveness of } \\
\text { postpartum family planning services. Results } \\
\text { indicate postpartum program increases } \\
\text { contraceptive prevalence and reduces } \\
\text { program costs. As a result of the project, } \\
\text { IPSS adopts postpartum family planning and } \\
\text { opens a training center. Principal investigator } \\
\text { becomes Pathfinder rep resentative in Peru, } \\
\text { research supervisor becomes AVSC } \\
\text { representative (1987-1990). }\end{array}$ & & $\begin{array}{l}\text { In collaboration with Pathfinder, INOPAL II } \\
\text { assists IPSS to scale-up project to four } \\
\text { hospitals. Lack of nurse-midwife } \\
\text { particip ation identified as barrier to greater } \\
\text { postp artum family planning acceptance } \\
\text { (1990-1992). }\end{array}$ \\
\hline$\downarrow$ & & $\downarrow$ \\
\hline OTHER S UPPORT & & $\begin{array}{l}\text { INOPAL helps introduce postpartum } \\
\text { family planning into the nurse-midwifery } \\
\text { curriculum of six Peruvian universities. In } \\
\text { other projects, HMOs in Brazil and Peru } \\
\text { (whose providers were trained by IPSS } \\
\text { training center staff) demonstrate that } \\
\text { postpartum family planning is cost- } \\
\text { beneficial(1992-1995). }\end{array}$ \\
\hline $\begin{array}{l}\text { The IPSS training center trains phy sicians } \\
\text { from Bolivia, Brazil, and the United States, as } \\
\text { well as } 129 \text { Peruvian ob-gyn residents and } \\
\text { interns (1990-1995). }\end{array}$ & & OTHER S UPPORT \\
\hline$\downarrow$ & & \\
\hline $\begin{array}{l}\text { Pathfinder begins large-scale postpartum } \\
\text { activities in Bolivia and Brazil with IPSS- } \\
\text { trained physicians who become trainers in } \\
\text { their own countries (1990-1995). }\end{array}$ & $\rightarrow$ & $\begin{array}{l}\text { Peru MOH adopts postpartum family } \\
\text { planning as a priority activity. Pathfinder } \\
\text { trains staff of } 24 \text { MOH hospitals and AVSC } \\
\text { trains staff of } 22 \text { IPSS and MOH hospitals } \\
\text { in postpartum family planning (1992-1995). }\end{array}$ \\
\hline
\end{tabular}




\section{INS TITUTIONALIZATION OF OPERATIONS RES EARCH CAPABILITY IN LATIN AMERICAN ORGANIZATIONS}

Institutionalization is a long complicated process. It requires stimulating the interest of the potential host in conducting OR and obtaining the human and material resources needed. INOPAL I indirectly pursued the goal of institutionalization of the ability to conduct OR. Local researchers were hired to be principal investigators on OR projects. Agencies were equipped with computers and research software; seminars, conferences, and newsletters disseminated OR results. INOPAL II directly encouraged organizations to adopt $\mathrm{OR}$ as a management tool by funding projects whose objective was institutionalization itself, and by holding several OR training workshops. The four agencies conducting institutionalization projects were:

n The School of Public Health (ESPM) of the Mexican National Institute of Health: The long-term sustainability of OR requires incorp oration into academic programs. ESPM is seeking a leadership role in Latin America in the areas of health management and Operations Research. As part of this effort, ESPM received INOPAL assistance to strengthen OR activities. ESPM created a library of materials on Operations Research, and offers courses on OR as part of the regular graduate and continuing education curricula. Students are also provided with the op portunity to work on actual OR projects.

Since most Mexican public health officials are trained at ESPM, institutionalization should result in increased use of OR as a routine management tool. ESPM also plans to provide short courses on Operations Research to students from other Latin American countries. ESPM is located in Cuemavaca, Mexico, and about 85 students complete graduate studies at the school every year.

$\mathrm{n}$ The Family Planning Directorate (DGPF) of the Ministry of Health of Mexico: The Mexican national family planning program has for many years included OR among the duties of its research and evaluation units. With INOPAL II help, the DGPF succeeded in having state-level family planning authorities institutionalize OR.

The MOH invited state managers to attend an OR workshop to develop OR proposals for their local programs. The call for participants drew a response far exceeding the 20 spaces available at the seminar. Participants leamed OR basics and were organized into teams to write proposals. The three best proposals were awarded grants of approximately $\$ 6,500$. The successful implementation of research projects by participants demonstrated that local programs can diagnose and solve operational problems. Moreover, local involvement in selecting priorities and designing solutions to be tested resulted in high levels of interest and participation in the projects.

The DGPF now conducts regular evaluation and OR workshops where each state presents information on local family planning program progress. An early achievement of these workshops was the establishment of common quality and quantity indicators. Workshops now focus on specific problems such as service quality, training, and institutional development.

n Most family planning organizations do not have the resources to support a full-time research staff. However, they can develop a capacity to conduct limited types of OR. CEMOPLAF of Quito, 
Ecuador, is developing the ability to conduct research on cost and sustainability issues. MEXFAM, the Mexican IPPF affiliate, institutionalized an OR technique called Continuous Quality Improvement (CQI) to improve program op erations.

CEM OPLAF, with assistance from INOPAL and Family Health International, trained 6-8 key staff members in topics including family planning indicators, cost analysis, sampling, and questionnaire design. The training built on the existing skills of agency administrators, accountants, and computer programmers. In the last y ear, the OR team has conducted studies of clinic and laboratory costs, client ability to pay, and the market for ultrasound services.

MEXFAM institutionalized CQI. On a continuous basis, groups of workers go through the steps of OR: (1) problem identification; (2) selection and testing of the solution; (3) evaluation of solution impact; and (4) dissemination of results and wider application of successful strategies. Qualityimp rovement teams were established in all clinics and program departments. After training, these teams were told to solve problems in their areas. At MEXFAM, CQI has produced changes in every thing from the comfort of clinic waiting rooms to accounting procedures. The Population Council and M SH used the MEXFAM materials to develop a CQI seminar and teaching materials. With funding from several different donors, the seminar has been held in M exico, Honduras, Nicaragua, and Bolivia.

\section{COLLABORATION}

Collaboration with other donor and technical assistance agencies is an essential ingredient for successful Operations Research. It builds a constituency for OR and provides reliable feedback on the success of different strategies for program improvement.

Participation by USAID Cooperating Agencies (CAs) and others also improves the quality of OR. CAs are sources of information about potential host agencies, their problems, and possible solutions. CAs also offer high-quality expertise in training, logistics, communications, etc., which results in higher quality service-delivery interventions. Finally, because they have a stake in the research, CAs are more likely to scale-up projects in which they participated.

During INOPAL II, the Population Council worked with $23 \mathrm{CAs}$ and other international agencies. Collaboration included joint funding and technical assistance to OR/TA projects, workshops, and seminars; and production and reprinting of dissemination materials. With deep appreciation, the Population Council acknowledges the work of our collaborators: 
INOPAL II

Donor and technical assistance agency collaborators

\begin{tabular}{|c|c|}
\hline AGENCY & JOINT ACTIVITY COUNT RIES \\
\hline $\begin{array}{l}\text { ASSOCIAT ION FOR VOLUNT ARY } \\
\text { SURGICAL CONT RACEPTION }\end{array}$ & MEXICO, PERU \\
\hline CARE & BOLIVA, GUATEMALA, HONDURAS, PERU \\
\hline COLUMBIA UNIVERSITY & REGIONAL \\
\hline DAI & $\begin{array}{l}\text { BOLIVA, DOMINICAN REPUBLIC, ECUADOR, } \\
\text { HONDURAS, MEXICO, PERU }\end{array}$ \\
\hline DEMOGRAPHIC HEALTH SURVEY & PERU, REGIONAL \\
\hline FAMILY CARE INTERNATIONAL & BOLIVA \\
\hline FAMILY HEALTH INTERNATIONAL & BOLIVA, ECUADOR, MEXICO \\
\hline THE FUT URES GROUP & BRAZIL, ECUADOR, PERU \\
\hline GEORGETOWN UNIVERSITY & BRAZIL, HONDURAS \\
\hline $\begin{array}{l}\text { INTERNATIONAL PLANNED } \\
\text { PARENT HOOD FEDERAT ION/ } \\
\text { WEST ERN HEMISPHERE REGION }\end{array}$ & $\begin{array}{l}\text { COLOMBIA, HAIT I, HONDURAS, NICARAGUA, } \\
\text { MEXICO, REGIONAL }\end{array}$ \\
\hline JHPIEGO & PERU \\
\hline JOHN SNOW, INC. & BOLIVA \\
\hline MANAGEMENT SCIENCES FOR HEALTH & BOLIVA, MEXICO, REGIONAL \\
\hline PATHFINDER & BOLIVA, ECUADOR, MEXICO, PERU \\
\hline PROJECT CONCERN & GUATEMALA \\
\hline PLAN & HONDURAS \\
\hline SAVE THE CHILDREN & HONDURAS \\
\hline TVT/MORE & REGIONAL \\
\hline UNIT ED NATIONSPOPULATION FUND & PERU \\
\hline UNIVERSITY OF MICHIGAN & REGIONAL \\
\hline WELLST ART & PERU \\
\hline WORLD NEIGHBORS & BOLIVA, ECUADOR \\
\hline WORLD VISION & HONDURAS \\
\hline
\end{tabular}

